[Vicino Oriente XXIII (2019), pp. 155-184]

\title{
ISLAMIC CLAY FIGURINES FROM EXCAVATIONS AT ISTAKHR AND A SUGGESTED USE OF THE ANIMAL-SHAPED SPECIMENS*
}

\author{
Maria Vittoria Fontana - Serenella Mancini \\ Sapienza University of Rome
}

This paper deals with the Islamic hand-modelled clay figurines from the excavations carried out at Istakhr (Fars region, Iran) by the Oriental Institute of Chicago in the 1930s and the Joint ItalianIranian Archaeological Mission in 2012. S. Mancini presents detailed descriptions of these artefacts, including some technological notes relating to fabrics, as well as a few comparisons help to propose their chronological attribution. M.V. Fontana suggests that the animal specimens can be understood as figurines which children usually placed on the roofs of their houses pending the end of panji-mas and to welcome in the New Year at the end of a long-lasting ritual of Zoroastrian tradition, as can also be seen in some Seljuk glazed ceramic "house models".

Keywords: Istakhr; Seljuk period; hand-modelled clay figurines; animal-shaped specimens; ceremony of Zoroastrian tradition

\section{THE ISLAMIC HAND-MODELLED CLAY FIGURINES FROM EXCAVATIONS CARRIED OUT IN THE 1930S AND 2012 AT ISTAKHR}

The archaeological area comprising the mound of the "historical city" of Istakhr is located in the Fars province, roughly $60 \mathrm{~km}$ north of Shiraz and approximately $5 \mathrm{~km}$ north of Persepolis. ${ }^{1}$

This contribution discusses an interesting group of fifteen Islamic hand-modelled clay figurines brought to light during excavations carried out at Istakhr in the 1930s and 2012 (figs. 1-4), ${ }^{2}$ which will be analysed in detail hereafter.

\subsection{The Islamic clay figurines from Istakhr: description}

The three figurines from the 2012 excavations (nos. 3-4 and 15, figs. 2 and 4) and just two of the twelve figurines from the 1930s excavations (nos. 7 and 14, figs. 2 and 4), respectively preserved in storage at the Persepolis Museum and the Oriental Institute Museum of Chicago, have been directly examined by the author. Consequently only the fabrics of these figurines have been described here, while information on the fabrics of the

* Three fragments were uncovered in 2012 by the joint Italian-Iranian Archaeological Mission at Istakhr (sponsored by Sapienza University of Rome, Rome - the Italian Ministry of Foreign Affairs and International Cooperation - the Max van Berchem Foundation, Geneva); twelve fragments were retrieved in the 1930s by the Archaeological Mission of the Oriental Institute of Chicago. The authors are deeply grateful to Jean Evans, the Chief Curator and Deputy Director of the Oriental Institute Museum of the University of Chicago, and Donald S. Whitcomb and Tasha Vorderstrasse, respectively Associate Professor and Research Associate at the Department of Near Eastern Languages and Civilizations of the Oriental Institute of the University of Chicago, for allowing Serenella Mancini to view the materials and all related data preserved at the Oriental Institute Museum, as well as the publication of photos and drawings.

1 For a comprehensive history of the field works carried out at Istakhr, starting with Herzfeld's first surveys in 1923, see Fontana ed. 2018 and, in particular, Rugiadi’s paragraph "\$2.2. Historical trenches on the ground" in Rugiadi - Colliva 2018, 133-138, and Di Cesare in Di Cesare - Ebanista 2018, 257-267.

2 On behalf of the Oriental Institute of Chicago (1930s), and Sapienza University of Rome and ICHHTO of Tehran (2012), respectively.

ISSN 0393-0300

e-ISSN 2532-5159

Rivista Open Access 
other figurines found during the 1930s excavations (nos. 1-2, 5-6, 9-13, figs. 1-4) - whose location is presently unknown - is provided in the final table 1, as taken from the descriptive cards accompanying the drawings of the figurines and currently kept in the Oriental Institute Museum. ${ }^{3}$ The fabrics examined range from light yellow to brown. The figurines inspected are solid rather than hollow.

The final table 1 also contain all the available information on dimensions and find spots.

1.1.1. Nos. 1-2 - Two saddleless horses with riders (fig. 1)

Two figurines portray saddleless horses with riders (the so-called horse-and-rider type); they were modelled separately and then assembled. Only no. 1 is almost complete and features a rider holding the horse's mane, whereas in no. 2 only part of the rider's legs have been preserved and the rest of the body has been completely lost.

Three legs of horse no. 1 have been lost, the neck is short and bent forward and the tail is missing. The rider, which seem to be merely sketched, is small and has no remarkable features. The head of horse no. 2 has also been lost and its two left legs and tail are missing.

\subsubsection{Nos. 3-9 - Seven horses (or six horses and a giraffe) (fig. 2)}

The horse-shaped figurines are the most numerous and are characterised by several small details; in most cases they are fragmentary. The backs of those that have been preserved are fitted with saddles. The latter are made of two clay fillets - placed transversely or centrally - which were modelled separately and then applied, except for the saddles of figurines 5 and 7 which were modelled during the manufacturing process.

Only one horse still has its head (no. 5), while only the head remains of horse no. 8 . Two small clay buttons with a central circular impression have been applied to form the eyes of both figurines; horse no. 8 also has triangular ears.

Nos. 3-5 and 8-9 have modelled and incised manes (nos. 3, 5 and 9 also feature painted lines). Specifically, the considerable length of the neck of figurine no. 9 could lead to the identification of this animal as a giraffe. The stylised legs, which are missing from most of the artefacts, have rounded or flat ends. The tails, recognisable in only four specimens (nos. 3, 6-7, 9), have been applied on horses nos. 3, 6 and 7

The fabrics of nos. 3-4 and 7 are described below.

Figurine no. 3 was made with a grey/buff quite fine fabric of medium/high compactness and a chalky feel to the touch. This fabric has few mineral inclusions which are most likely found in the clay matrix in its natural state. It has a porosity of $2 \%$; the voids have an elongated sub-angular shape and range in size from 0.1 to $0.4 \mathrm{~mm}$. Figurine no. 4 has a reddish/pinkish fabric and elongated sub-angular dark red-brown mineral inclusions, ${ }^{4}$ probably argillaceous rock fragments. ${ }^{5}$ Figurine no. 7 has a medium/coarse dark brown fabric with sparse black mineral inclusions; this very hard fabric is highly compact.

3 The author wishes to express her special gratitude to three staff members of the Oriental Institute Museum of Chicago: Helen McDonald and Susan Allison, respectively Registrar and Associate Registrar, and Anne Flannery, Head Archivist, for helping her in the research and archive consultation.

4 These fabrics were widely used to produce most of the unglazed wares found at Istakhr and a few pieces of kiln furniture brought to light during the excavations (Fusaro 2016, 87).

5 See Whitbread 1986 for the characterisation of argillaceous rock fragments (ARF). 


\subsubsection{Nos. 10 and 11 - Two camels (figs. 3-4)}

Two figurines have been identified as camels (camelus dromedarius). Camel no. 10 (fig. 3) is preserved in its entirety with a long-curved neck, the lower part of which is thicker; the muzzle juts out and the two ears are triangular, the body is very stylised and the four legs have been finished with a flat tool. ${ }^{6}$ A saddle composed of two projecting elements has been applied on the back of the animal.

Only the head of camel no. 11 (fig. 4) remains. It is more detailed than that of no. 10 and has a round shape, a protruding muzzle, an open mouth, and small ears placed horizontally.

\subsubsection{No. 12 - A horned animal (fig. 3)}

Figurine no. 12 is preserved in its entirety and represents a horned animal, probably a gibbous ox (bos indicus). ${ }^{7}$ The two horns are very thick and arch back slightly, the muzzle is stylised, and the neck is short and stocky. The body is medium size, the legs were finished with a flat tool, and a hump has been placed on its back.

\subsubsection{No. 13 - Cat or lion (fig. 4)}

Only the front part of figurine no. 13 is preserved. This quadruped is very stylised: its ears are arched back, its eyes are formed by two small applied clay buttons with a central circular impression and its small nose is merely outlined. The descriptive card identifies it as a cat, but it could also be a lion. ${ }^{8}$

\subsubsection{Nos. 14-15 - Two unidentified quadrupeds (fig. 4)}

Figurine no. 14 is partially preserved and features an unidentified quadruped. The back part has a well-worked body and the two rear legs are broken at their tips. The short tail seems to have been modelled during the manufacturing process, as it is positioned horizontally and slightly upturned. It is very interesting to note that a clay fillet has been applied to the animal's back also around its tail, suggesting it could be a sort of harness. This figurine was made with a medium/coarse buff fabric with irregular and elongated black temper. The fabric has a porosity of 5/7\% and the voids are rounded and irregular.

The only remaining part of figurine no. 15 is a quadruped's leg, which, as usual, is highly stylised. The fabric is the same as that used for horse figurine no. 4 , i.e. a medium/ coarse reddish/pinkish fabric with dark red-brown mineral inclusions.

6 See Schmidt 1939, fig. 85 and https://oi.uchicago.edu/gallery/istakhr-islamic-city-mound\#9F12_72dpi.png; cf. also Gibson 2010, I, 54, fn. 44.

See Schmidt 1939, fig. 85 and https://oi.uchicago.edu/gallery/istakhr-islamic-city-mound\#9F12_72dpi.png; cf. also Gibson 2010, I, 54, fn. 44. For Iran as one of the zoological contexts of the bos indicus, see Brunner 1980,35 .

8 Cf. Fontana, below, and figs. 8-10. 


\begin{tabular}{|c|c|c|c|c|c|}
\hline NOS. & FINDSPOTS & $\begin{array}{l}\text { IDENTIFICATION } \\
\text { NUMBERS }\end{array}$ & \begin{tabular}{|c|} 
EXCAVATION \\
DATES
\end{tabular} & SIZES & NOTES \\
\hline 1 & FH - 50 & $\begin{array}{l}\text { Saddleless horse with } \\
\text { rider } \\
\text { I } 2779\end{array}$ & $1930 \mathrm{~s}$ & $6.4 \times 7.4 \mathrm{~cm}$ & $\begin{array}{l}\text { Fabric and pigments not examined; «grey } \\
\text { medium fabric, medium/ hard» }\end{array}$ \\
\hline 2 & $\begin{array}{c}\text { GL }-45 \mathrm{~N} \text { side } \\
\text { OW }\end{array}$ & $\begin{array}{l}\text { Saddleless horse with } \\
\text { rider } \\
\text { I } 2163\end{array}$ & $1930 \mathrm{~s}$ & $6.2 \times 6.8 \mathrm{~cm}$ & $\begin{array}{l}\text { Fabric and pigments not examined; «buff } \\
\text { colour» }\end{array}$ \\
\hline 3 & SU133 & $\begin{array}{c}\text { Horse } \\
-\end{array}$ & 2012 & $5.8 \times 5.4 \mathrm{~cm}$ & $\begin{array}{l}\text { Grey/buff quite fine fabric of medium/ } \\
\text { high compactness and a chalky feel to the } \\
\text { touch. This fabric has few mineral } \\
\text { inclusions which are most likely found in } \\
\text { the clay matrix in its natural state. It has a } \\
\text { porosity of } 2 \% \text {; the voids have an } \\
\text { elongated sub-angular shape and range in } \\
\text { size from } 0.1 \text { to } 0.4 \mathrm{~cm} \text {. Red painted lines } \\
\text { on body. }\end{array}$ \\
\hline 4 & SU102 & $\begin{array}{l}\text { Horse } \\
\text { ES31 }\end{array}$ & 2012 & $6.4 \times 7.7 \mathrm{~cm}$ & $\begin{array}{l}\text { Reddish/pinkish fabric and elongated } \\
\text { sub-angular dark red-brown mineral } \\
\text { inclusions, probably argillaceous rock } \\
\text { fragments }\end{array}$ \\
\hline 5 & $\mathrm{FH}-50$ & $\begin{array}{l}\text { Horse } \\
\text { I } 2780\end{array}$ & $1930 \mathrm{~s}$ & $6.7 \times 6.9 \mathrm{~cm}$ & $\begin{array}{l}\text { Fabric and pigments not examined; } \\
\text { «yellow/grey colour, red painted lines on } \\
\text { neck» }\end{array}$ \\
\hline 6 & GL-15 NO & $\begin{array}{l}\text { Horse } \\
\text { I } 2120\end{array}$ & $1930 \mathrm{~s}$ & $6.3 \times 8.5 \mathrm{~cm}$ & $\begin{array}{l}\text { Fabric and pigments not examined; «buff } \\
\text { medium/fine fabric, medium/ hard» }\end{array}$ \\
\hline 7 & IL-16 & $\begin{array}{l}\text { Horse } \\
\text { I } 2 \text { 1389-m }\end{array}$ & $1930 \mathrm{~s}$ & $3.6 \times 8 \mathrm{~cm}$ & $\begin{array}{l}\text { Medium/coarse dark brown fabric with } \\
\text { sparse black mineral inclusions; this very } \\
\text { hard fabric is highly compact }\end{array}$ \\
\hline 8 & FH-30 & $\begin{array}{l}\text { Horse } \\
\text { I } 2135\end{array}$ & $1930 \mathrm{~s}$ & $5.3 \times 1.9 \mathrm{~cm}$ & $\begin{array}{l}\text { Fabric and pigments not examined; } \\
\text { «yellow/brown fine fabric, medium/ hard» }\end{array}$ \\
\hline 9 & GL-35 NW & $\begin{array}{l}\text { Horse or giraffe } \\
\text { I } 2101\end{array}$ & $1930 \mathrm{~s}$ & $9.2 \times 6.8 \mathrm{~cm}$ & $\begin{array}{l}\text { Fabric and pigments not examined; } \\
\text { «red/grey colour, red paint» }\end{array}$ \\
\hline 10 & - & $\begin{array}{l}\text { Camel } \\
\text { I } 2437 \\
\end{array}$ & $1930 \mathrm{~s}$ & & Fabric and pigments not examined \\
\hline 11 & GL - 45 & $\begin{array}{l}\text { Camel } \\
\text { I } 2701\end{array}$ & $1930 \mathrm{~s}$ & $4 \times 3.8 \mathrm{~cm}$ & $\begin{array}{l}\text { Fabric and pigments not examined; «grey } \\
\text { medium/coarse fabric, medium/hard» }\end{array}$ \\
\hline 12 & - & $\begin{array}{l}\text { Horned animal } \\
\text { I } 2427\end{array}$ & $1930 \mathrm{~s}$ & & Fabric and pigments not examined \\
\hline 13 & $\begin{array}{c}\text { GL - 24 Sherd } \\
\text { pile }\end{array}$ & $\begin{array}{l}\text { Cat or lion } \\
\text { I } 2362\end{array}$ & $1930 \mathrm{~s}$ & $3.8 \times 4.3 \mathrm{~cm}$ & $\begin{array}{l}\text { Fabric and pigments not examined; «light } \\
\text { yellow colour, medium/ hard» }\end{array}$ \\
\hline 14 & HL-76 & $\begin{array}{l}\text { Unidentified } \\
\text { quadruped } \\
\text { I } 2 \text { 1383-o }\end{array}$ & $1930 \mathrm{~s}$ & $3.3 \times 4.7 \mathrm{~cm}$ & $\begin{array}{l}\text { Medium/coarse buff fabric with irregular } \\
\text { and elongated black temper; the fabric } \\
\text { has a porosity of } 5 / 7 \% \text {, the voids are } \\
\text { rounded and irregular }\end{array}$ \\
\hline 15 & SU129 & $\begin{array}{l}\text { Unidentified } \\
\text { quadruped } \\
-\end{array}$ & 2012 & $4.6 \times 2.2 \mathrm{~cm}$ & $\begin{array}{l}\text { Reddish/pinkish fabric and elongated } \\
\text { sub-angular dark red-brown mineral } \\
\text { inclusions, probably argillaceous rock } \\
\text { fragments }\end{array}$ \\
\hline
\end{tabular}

Tab. 1 - Description of figurines found during the 1930s excavations. ${ }^{9}$

9 The descriptions of fabrics and pigments in quotation marks in the 'notes' column were taken from the descriptive cards preserved at the Oriental Institute Museum of Chicago. 


\subsection{The Islamic clay figurines from Istakhr: comparison and dating}

Clay figurines in the shape of both humans and animals have been found at numerous archaeological sites in Iran, Iraq and Central Asia, ${ }^{10}$ nevertheless it is quite complicated to find meaningful comparisons. At Istakhr only two clay figurines of the so-called and widespread horse-and-rider type have been found. ${ }^{11}$ As for the Sasanian and Islamic periods we can cite the Sasanian finds from Vēh Ardashīr and Merv ${ }^{12}$ and the Islamic specimens found at Wāsit and Fusțāt. ${ }^{13}$

The clay figurines from Istakhr have a distinct stylised character which also seems to be a dominant feature in clay figurines from other sites. This aspect is highly recognisable in most clay animal figurines from Islamic Susa. These usually represent quadrupeds and especially horses which have simply modelled bodies (fig. 5a), four legs shaped together in an extended position, and legs that are often rounded or flat at the end. Paint has also been used to highlight some parts of the animals' bodies, in particular the manes. ${ }^{14}$ The chronological attribution of clay animal figurines from Susa is based on ceramic findings: a dating between the $7^{\text {th }}$ and $9^{\text {th }}$ centuries has been suggested.

The figurine found at Tell Abū Sarīfa, whose dating is uncertain but certainly not before the $9^{\text {th }}$ century ${ }^{15}$ also has some elements in common with the Istakhr specimens: the handmodelled stylised horse with outspread legs also bears traces of decorative bands of red paint (fig. 5b). ${ }^{16} \mathrm{~A}$ wide range of figurines found at Wāsit have been dated to the $13^{\text {th }}$ century. They are made with «fine-grained clay, buff in colour or slightly pink according to firing ${ }^{17}$ and have a strongly stylised character seen especially in the quadrupeds with sketched features: their bodies and muzzles share characteristics with the specimens from Istakhr (fig. 5 c). ${ }^{18}$ Black and/or red paint was also found on some parts of the animals' bodies. ${ }^{19}$

Another comparable feature is the saddle. The saddles of the animal figurines from Istakhr, Susa (fig. 5a) and Wāsit were made by applying two clay fillets across the back of the quadrupeds: they are composed of two rounded or pointed shaped pieces. ${ }^{20}$

The three clay figurines from Istakhr unearthed during the excavations carried out in 2012 (nos. 3-4 and 15, figs. 2 and 4) can be dated to the Seljuk period. In fact, they were found in phases 5,7 and 8 , and date from the $11^{\text {th }}$ to the early $13^{\text {th }}$ century on the basis of

10 Especially for animal figurines, see below, Fontana 2.1.

11 The horse-and-rider theme was widely represented during the Sasanian period and in some cases, as we can see at Istakhr, it even survived in the Islamic period.

12 On Vēh Ardashīr Cellerino and Messina $(2013,124)$ stated «[...] conforming to a trend already attested from the Hellenistic to the Sasanian period, figurines of horses largely prevail, for they were used for the most, to support riders [...]». For Merv see Simpson 2004, 324 and Herrmann et al. 1997, 9 (cf. also fn. 57, below)

13 See Safar 1945, pl. XXI $a$ for Wāsit; Scanlon 1968, 2, text fig. 2a on p. 4, and fig. 1c for Fusțāṭ (cf. also fn. 25, in fine, below).

Rosen Ayalon 1974, figs. 248-249, 254-255

5 Cf. Wells (2015, 55-57), who has postdated the finds from Tell Abū Sarīfa (Adams 1970, 118).

As for the Istakhr red painted horse (and giraffe) figurines cf. nos. 3, 5 and 9 (table 1).

Safar 1945, 36 .

Safar 1945, pl. XXII $a$.

Safar 1945, 36.

See Rosen Ayalon 1974, figs. 247-250, Kervran 1977, fig. 49.6, pl. XII.1; 1984, fig. 30.5 for Susa; Adams 1970, pl. 8, figg. 16e (here, fig. 5b) for Tell Abū Sarīfa; Safar 1945, pl. XXIIa (top left) for Wāsiț. Similar saddles can be seen on horse figurines from Nishapur, dated to the $9^{\text {th }}-12^{\text {th }}$ century (Wilkinson 1973, ill. 130 on p. 354) and Tell Abū Șkhayr, dated to the $13^{\text {th }}$-mid- $14^{\text {th }}$ century (Shammri 1986, fig. 33d). 
pottery finds. ${ }^{21}$ We can also suggest a similar date for the figurines found during excavations carried out in the 1930 s, for which we do not yet have precise information on the stratigraphy. ${ }^{22}$ This dating corresponds to that attributed to figurines with similar features found in Wāsit, i.e. the so-called Seljuk revival that occurred in Iraq during the $12^{\text {th }}-13^{\text {th }}$ centuries. $^{23}$

Serenella Mancini

\section{THE ISLAMIC ANIMAL-SHAPED CLAY FIGURINES FROM ISTAKHR, AND LATE SASANIAN AND ISLAMIC SPECIMENS FROM SOME ARCHAEOLOGICAL SITES IN IRAN, IRAQ AND CENTRAL ASIA, AND THEIR SUGGESTED USE}

This contribution deals with the Islamic animal-shaped clay figurines found during excavations carried out at Istakhr in the 1930s and 2012 (figs. 2-4). ${ }^{24}$ The figurines include different kinds of quadrupeds, along with saddled horses and camels - and perhaps also a giraffe - with no rider. The figures with horsemen (which may have originated from the socalled horse-and-rider type), on the contrary, are portrayed riding without saddles. As discussed below, the saddles may indeed be pack saddles, which would indicate that the quadrupeds wearing them were pack animals.

As Serenella Mancini has illustrated, the Istakhr finds include, in addition to two saddleless horses with riders (nos. 1-2, fig. 1), five saddled horses (nos. 3-7, fig. 2), a saddled horse or giraffe (no. 9, fig. 2), a saddled camel (no. 10, fig. 3), a horned animal, most probably a gibbous ox (no. 12, fig. 3), a cat or lion (no. 13, fig. 4), a horse's head (no. 8 , fig. 2), a camel's head (no. 11, fig. 4) and two unidentifiable quadrupeds (nos. 14-15, fig. 4).

\subsection{Late Sasanian and Islamic clay animal figurines from Iran, Iraq and Central Asia}

Some clay animal figurines have been found from the Late Sasanian and Islamic strata of archaeological sites in Iran, Iraq and Central Asia. ${ }^{25}$

21 Serenella Mancini, La ceramica di Estakhr (Iran): classificazione, studio e confronti, PhD Thesis, Sapienza University of Rome, Rome, in progress. Some figurines are certainly of local production, cf. above, fn. 4.

22 Donald Whitcomb and Tasha Vorderstrasse are currently working on the documentation of those excavations.

23 Safar 1945, 37; cf. Adams 1970, 116.

24 See the previous contribution by Serenella Mancini, in particular fns. 1 and 2. The animal specimens constitute the overwhelming majority of unearthed figurines from Istakhr.

25 Only these three great areas (included in Greater Iran) have been taken into account and all comparisons with clay animal figurines dated prior to the Late Sasanian era have been omitted. In fact, the oldest Sasanian animal figurines - such as those from the excavations of the so-called Artisan Quarter of Vēh Ardashīr (in the al-Madā' in area in Iraq, $3^{\text {rd }}-5^{\text {th }}$ century, investigated by the Italian Expedition in Iraq of the Centro Ricerche Archeologiche e Scavi di Torino per il Medio Oriente e l'Asia; cf. Invernizzi 1979; 1985, figs. on p. 193; Cellerino - Messina 2013) -, although for the most part also hand-modelled, with very few exceptions (cf. fn. 95, below) show iconographic features and stylistic renderings markedly different from those exhibited by the more recent samples, since the former share the characteristics of specimens extremely widespread in the Ancient Near East from the Neolithic period onwards. Even their intended uses - including ritual, magic-cult, funerary, and so on - do not allow comparisons (cf. Parayre 2003). As for the "other" areas of origin, Gibson (2010. I, 54 and fn. 43) reported a figurine in the form of a horse from Fusțāt (Egypt), but in fact it belongs to the widespread horse-and-rider type (Scanlon 1968, 2, text fig. 2a on p. 4, and fig. 1c). 


\subsubsection{Animal figurines from Iran}

Among the Iranian finds, Donald S. Whitcomb said of the clay animal figurines found during the excavations carried out by the Oriental Institute of Chicago at Qașr-i Abū Nașr (old Shiraz, located in the Fars region like Istakhr): they are numerous and include «mainly ambiguous quadrupeds» and two fragmentary saddles, dating to the Sasanian-Early Islamic period. $^{26}$

In Susa (present-day Shush, in the Khuzistan province), one of the most ancient cities of the region, the Délégation Archéologique en Iran brought to light a very impressive quantity of clay figurines dating from the $4^{\text {th }}$ millennium BCE onwards, ${ }^{27} 755$ of them were animal specimens, the dating of which was sometimes contested. ${ }^{28}$ Myriam Rosen-Ayalon dated some twenty clay animal figurines found during the excavations carried out in the royal city to the Islamic period: they were divided among the Louvre Museum, the National Museum in Tehran and the former storerooms of the French Archaeological Mission in both Susa and Tehran. ${ }^{29}$ Most of them are horses, and those whose bodies are preserved are fitted with saddles (fig. 5a). ${ }^{30}$ All that is left of other two horses are their heads. ${ }^{31}$ Two unidentifiable quadrupeds and two birds are also found. ${ }^{32}$ Some figurines are painted red and/or black. ${ }^{33}$ As for their attribution to the Islamic period and, more specifically, to the $7^{\text {th }}-9^{\text {th }}$ century, I would suggest caution, as some figurines could still be dated to the Sasanian period while others could be dated later than the $9^{\text {th }}$ century. ${ }^{34}$ During subsequent excavations of the sector between the royal city and the Apadana only a few fragments of animal figurines were found, namely horses also dated to the $8^{\text {th }}-9^{\text {th }}$ century, of which Monique Kervran published a saddled horse. ${ }^{35}$

26 Whitcomb 1985, 190 and fig. 72d-i. Unfortunately the poor conditions of the artefacts prevent us from recognising their morphological features and, consequently, the animal species to which the quadrupeds belong.

27 Martinez-Sève 2002; see also Spycket 1992.

28 Martinez-Sève 2003.

29 Rosen-Ayalon 1974, 113-121.

30 The saddles are applied (Rosen-Ayalon 1974, figs. 247-252, 256; pls. XXV.a, c, XXVI.c), a part of in two cases where it seems that they were modelled together with the body of the animals (Rosen-Ayalon 1974, figs. 254-255). Even a two-headed horse with a saddle should be reported (Rosen-Ayalon 1974, figs. 259-259a), while another two-headed horse ridden by a naked woman does not have a saddle (Islamic?, cf. fn. 34, below; Rosen-Ayalon 1974, fig. 258-258a).

31 Rosen-Ayalon 1974, fig. 253 and pl. XXV.b. The heads of another three horses have very different features, stressing that they were most likely produced for artistic purposes (Rosen-Ayalon 1974, figs. 264-266, pl. XXV.e; cf. Joel - Peli 2005, fig. 317 on p. 231; see also fn. 34 below)

32 Rosen-Ayalon 1974, figs. 262-263; fig. 268 and pl. XXV.g, respectively. Another bird is most likely a rattle (Rosen-Ayalon 1974, fig. 269, cf. also Joel - Peli 2005, cat. and ill. 319 on p. 232).

33 Rosen-Ayalon 1974, figs. 251-256.

34 In addition to the previously mentioned two-headed horses, one of which also ridden by a naked woman (cf. fn. 30, above), the three horse heads of horses have very different modelling, which is much more complex and refined (cf. fn. 31, above; Rosen-Ayalon 1974, figs. 264-266, pl. XXV.e; for the last one cf. also Joel Peli 2005, cat. and ill. 317 on p. 231, where it is also specified that « ce petit cheval présente la particularité d'être creux »). Rosen-Ayalon herself pointed out that the last horse figurine, published in 1954 by Jean DavidWeill, was dated by this scholar to the Sasanian period (Rosen-Ayalon 1974, 120, fn. 1). Whereas, the provenance of an opaque-glazed and lustre painted figurine of a probable lion from the «niveau 2 », attributed to the $8^{\text {th }}-9^{\text {th }}$ century, is sufficient evidence to resort to a new and later dating of that layer, from which not many clay figurines were found.

35 Kervran 1977, 150, no. 6, fig. 49.6, pl. XII.1; 1984, 142, fig. 30.5. 
Charles K. Wilkinson reported that clay modelled figurines of uncertain date $\left(9^{\text {th }}-12^{\text {th }}\right.$ century) had been found during excavations by the Metropolitan Museum of Art in the Nishapur area in the Khurasan region, along one of the most important trade routes. These figurines are preserved in the Metropolitan Museum of Art in New York and the National Museum of Iran in Tehran. A horse figurine equipped with a saddle «formed from two added pieces of clay» was found on the surface at Sabz Pushān. ${ }^{36} \mathrm{~A}$ «hen» figurine was uncovered at Qanāt Tepe. ${ }^{37}$

Some clay figurines, belonging to the Islamic period but again of uncertain date, were found in Siraf, the famous ancient port of the Persian Gulf, and Rayy, the well-known manufacturing centre in the current province of Tehran, respectively. In her archaeological study of the ceramics ( $8^{\text {th }}$ to $15^{\text {th }}$ century) from Siraf preserved in the British Museum in London, ${ }^{38}$ Moira Tampoe referred to clay animal figurines, likely horses or mules, one of which is fitted with a saddle, while she suggested that a figurine with a «heavy rounded shape» might be an elephant. ${ }^{39}$

The excavations undertaken by Erich F. Schmidt (The Boston Museum of Fine Arts / University Museum Expedition to Rayy), which started in the spring of 1934 and concluded in the fall of $1936,{ }^{40}$ unearthed around 35 clay animal figurines which are now preserved in the Penn Museum in Philadelphia; ${ }^{41}$ six of them are painted. ${ }^{42}$ Their entries in the Museum website are not accompanied by illustrations and the animal species are not described, except in three cases: possibly a ram, a ram's head and the horn of an animal. ${ }^{43}$

Lastly, Muhammad Yussuf Kiani dated from the $10^{\text {th }}$ to $13^{\text {th }}$ centuries some running or standing clay animal figurines from the excavations he directed in Gurgan between 19701977.44

36 Wilkinson 1973, 325, no. 130, ill. 130 on p. 354. It is kept in the Metropolitan Museum of Art, New York (MMA 38.40.102), also quoted by Gibson 2010, I, 54, fn. 44; for colour images showing it from four different sides and its $9^{\text {th }}$-century suggested dating see https://www.metmuseum.org/art/collection/search/449314 (last access: 18/06/2019).

37 MMA 40.170.206. It was curiously described as having three legs «one at the front, two at the back» (Wilkinson 1973, 324, no. 119). Other two assumptive figurines were found in Nishapur, but Wilkinson was doubtful whether they were really such or applied ornaments: an elephant's head (in the National Museum, Tehran) and a monkey [or sheep]'s head (MMA 40.170.162): the former from Qanāt Tepe and the latter from Village Tepe (Wilkinson 1973, 324, no. 120; and 325, no. 126, ill. 126 on p. 354, respectively).

38 The excavations at Siraf began in 1966 and were carried out for seven seasons. They were directed by David Whitehouse under the co-direction of Gholam-Reza Masoumi, and sponsored by the British Institute for Persian Studies in London.

39 Tampoe 1989, 18, respectively nos. 731, 733 [or 735?], 736, and no. 734, illustrated at fig. 13 on p. 187.

40 See Schmidt 1940, 29 and ff.

41 https://www.penn.museum/collections/objects/site.php?irn=26\&object_name\%5B $\% 5 \mathrm{D}=$ animal+figurine (last access: 18/06/2019).

42 Object nos. CG842811-5020, CG842811-4281, CG842811-3612, CG842811-0154, CG842811-8515, 35-8-133

43 Object nos. 35-8-74, 35-8-70 and 37-11-381, respectively.

44 Gurgan, the former Astarābād, is the capital of the homonym historical province - recently re-named Gulistan - adjoining the south-east corner of the Caspian Sea. As far as the dating of the figurines, Kiani $(1984,79)$ did not propose a stratigraphic reference, but only affirmed: «In general these figurines are datable to the $4^{\text {th }}-7^{\text {th }}$ centuries A.H. $\left(10^{\text {th }}-13^{\text {th }} A D\right) »$. No description was given of the animal species or their forms, no illustration is available. 


\subsubsection{Animal figurines from Iraq}

Some clay animal figurines have also been found in Iraq. In Tell Abū Sarīfa (in the Nippur area, southern-east Iraq) one clay figurine was uncovered (from level IV, but near the bottom of level V) during the excavations jointly sponsored by the Oriental Institute of Chicago and the American Schools of Oriental Research. This figurine is a saddled horse with outspread legs, and its saddle has «an exceptionally high cantle and pommel» ${ }^{45}$ (fig. $5 \mathrm{~b})$. As some scholars have suggested, the dating to the $7^{\text {th }}$-late $8^{\text {th }}$ century proposed in 1970 by Adams should be shifted to the $9^{\text {th }}-10^{\text {th }}$ century due to the contextual findings of "Samarra Horizon" ceramics. ${ }^{46}$

During the excavations at Samarra directed by Friedrich Sarre and Ernst Herzfeld in 1911 and 1912-13 on behalf of the Islamic Department of the former Kaiser FriedrichMuseum in Berlin, two clay modelled animal figurines were uncovered from the $9^{\text {th }}$-century House VIIa, namely a cow - with carved details - and a fragmentary horse with applied saddle and bridle. ${ }^{47}$

A large amount of clay figurines were found in Tell Abū Șkhayr (al-Dawra, $2 \mathrm{~km}$ from Baghdad on the road to Babylon-Karbalā') and Wāsit (in eastern Iraq, half way between Küfa and Bassora on the west bank of the Tigris). During the three excavations campaigns carried out at Tell Abū Șkhayr in 1976-1978 by the State Organisation of Antiquities and Heritage of Baghdad, only animal figurines were brought to light. Hussain Abdul Amir Muhammad Shammri, the Deputy Director of the archaeological works, assigned them to two different periods: two quadrupeds (one might be a dog, no. 43) belong to Period I (early $13^{\text {th }}$ century), ${ }^{48}$ and ten pieces are dated to Period II $\left(13^{\text {th }}\right.$ to mid- $14^{\text {th }}$ century). Shammri identifies these ten animals as a lioness, a lion, two dogs, a duck, a giraffe, a mythical animal, a bear (?), a horse, and a hyena. ${ }^{49}$ It is noteworthy that the horse has a saddle, «formed from one added piece of clay». ${ }^{50}$

A large number of clay figurines came from excavations, that started in 1936 and lasted until 1942, carried out at Wāsit by the "Directorate General of Antiquities" of the Government of Iraq. The corresponding finds were housed in the Baghdad Museum. Fuad Safar specified that it was «one remarkable group of over four hundred pieces, found among the scanty remains of a building in the Ilkhânid levels of Sounding (shaft) No. 15, which we assume to have been a toy shop». ${ }^{51}$ Many of them are human figurines, however a considerable number of animal specimens were also unearthed. Unfortunately, Safar did not list the recognised animal species, but merely reported: «there are also riderless horses». ${ }^{52}$ Nevertheless, from the illustrations he published, several quadrupeds (including

45 Adams 1970, 116, 118 (for the level's dating), pl. 8 (fig. 16e). This figurine was also quoted by Gibson 2010 , I, 54 and fn. 44. Cf. also Mancini, above, $\S 1.2$.

46 See Wells 2015, 55-57.

47 Nos. 64 and 65, respectively (Sarre 1925, 18, figs. 52-53 on p. 17); both figurines are currently preserved in the Museum für Islamische Kunst, Berlin, Inv. Sam 160 [64] and Sam 168 [65].

48 Shammri 1986, 190, 192-193, no. 43, fig. 16d, pl. XLb on p. 536; no. 44, fig. 16e.

49 Shammri 1986, 268-269, 273-276, nos. 202-211, fig. 32 c-f on p. 480 and fig. 33 on p. 481, pl. LVIIIa-b on p. 554.

50 Shamri 1986, 276, no. 210, fig. 33 d.

51 Safar 1945, 36. Instead, Ernst J. Grube suggested it was likely the storeroom of a potter who specialised in manufacturing figurines (Grube 1966, 173; cf. also Graves 2008, 246, and 2010, I, 73).

52 Safar 1945,36 
some gibbous oxen, fig. 5c) and birds, counting at least one nightingale, can be identified. ${ }^{53}$ The horse recognisable at the top left of pl. XXII $a$ of Safar's volume wears a saddle. On the contrary, the horses with riders appeared not to be wearing saddles. ${ }^{54}$

\subsubsection{Animal figurines from Central Asia}

Finally, this next section discusses some clay animal figurines from Central Asia. ${ }^{55}$ All the animal figurines from Merv, a major oasis-city of Central Asia (in present-day Turkmenistan), have been dated to the Sasanian period $\left(5^{\text {th }}-7^{\text {th }}\right.$ century) ${ }^{56}$ They are handmodelled and «occasionally covered with a red slip or decorated after firing with a watersoluble red and/or black pigment». ${ }^{57}$ Many animal figurines were brought to light during the 1993 and 1994 campaigns from the «sixth-seventh century AD contexts». ${ }^{5}$ More specifically, St John Simpson referred to nineteen animal figurines, «mostly consisting of broken legs and/or hindquarters of quadrupeds, but including three recognizable horse figurines, two ovicaprids, a dog and a distinctive monkey-like creature».59 Only a few illustrations of animal figurines from Merv have been published, including those of three horses found in Area 5 of Gyaur Qal'a: a sufficient part of the body of one of them still remains, allowing us to observe its saddle. ${ }^{60}$ The «marks on the back where the riders sat» of two horse figurines - part of some surface findings from the "Chilburj" area - are most probably also saddles remains. ${ }^{61}$

In the National Museum of Samarkand some ceramic animal figurines found in Samarkand/Afrasiyab are preserved and dated to the $9^{\text {th }}-12^{\text {th }}$ century. The catalogue of a 1992-1993 touring exhibition held in three French museums illustrates two modelled specimens: a horned quadruped and a saddled horse. ${ }^{62}$

Three modelled animal figurines of quadrupeds found in Binket, the medieval capital of Shāsh (the Tashkent oasis), were illustrated in the catalogue of a 1991 exhibition in

53 Safar 1945, pl. XXII $a$, right.

54 Safar 1945, pl. XXI $a$. However, the quality of the photograph does not permit an optimal reading of it. M. Gibson reported a hand-modelled horse with red pigment and a large saddle, excavated at Kish (I think she was referring to Kish in Iraq, $12 \mathrm{~km}$ east of Babylon), dated to the $9^{\text {th }}-11^{\text {th }}$ century and preserved in the Victoria and Albert Museum, London, Inv. no. C.245.1931 (Gibson 2010, I, 54, fn. 44, and fig. 2 on p. 380).

55 For the long Central Asian tradition of clay figurines up to the $6^{\text {th }}$ century cf. Lo Muzio 2010.

56 During the 1996 campaign in Gyaur Qal'a, in the northern extension of Qal'a Area 4, «several figurine fragments» were found, in association with slip-painted wares, thus they could be dated to the Islamic period (up to the $10^{\text {th }}-11^{\text {th }}$ century). Firstly, however, it is not specified whether the lot also included animal figurines, and secondly, this finding was referred to as «residual small finds from earlier [?] periods» (Herrmann et al. 1997, 15). For a history of the archaeological work accomplished at Merv, see Puschnigg 2006, 9-16.

57 Simpson 2004, 324. Some specimens of Sasanian horse-and-rider types, some modelled (Simpson 2004, 324) and some moulded (Herrmann et al. 1997, 9), have also been found in Merv.

58 Simpson - Herrmann 1995, 141-142.

59 Simpson in Herrmann - Kurbansakhatov et al. 1994, 67; their date is uncertain.

60 «1: Head of red-slipped horse figurine with bridle (SF 10242 [Pl. Ia, ht. 7,6 cm], 2: body of horse figurine with saddle (SF 4978), 3: rear end of horse figurine (SF 10283)»: Herrmann et al. 2000, caption of fig. 1 on p. 3

61 Gaibov et al. 1990, 29; cf., above, the fragmentary saddles found at Qașr-i Abū Nașr, and also Wilkinson 1973, 325, no. 130. Both Gaibov et al. 1990 and Herrmann - Kurbansakhatov et al. 1994 mentioned other examples known from earlier investigations, citing Pugachenkova 1962, 143, 168, fig. 32

62 Inv. nos. A-37-26 and A-490-2, respectively (Samarcande 1992, 109, cat. nos. 250 and 251, ills. on p. 48). A moulded horned quadruped with rider is also displayed, Inv. no. A-530-I, dated to the $8^{\text {th }}$ century (? Samarcande 1992, 109, cat. no. 249, ill. on p. 48). 
Moscow. They are a camel, a harnessed horse and a saddled donkey, the last one also showing stripes painted with black engobe, all dated to the $11^{\text {th }}-12^{\text {th }}$ century and preserved in the Museum of History of the Peoples of Uzbekistan. ${ }^{63}$

The rather wide chronological span from the $5^{\text {th }}$ to $13^{\text {th }}\left(-14^{\text {th }}\right)$ centuries, which covers the production of the above-mentioned clay hand-modelled animal figurines, and their different models and renderings do not always enable close global parallels with Istakhr specimens. ${ }^{64}$ Nevertheless, some features, such as fairly coarse modelling, the outspread legs of the quadrupeds, the regular occurrence of saddles - mostly added - on the backs of both horses and, in some cases, other four-legged animals - camels, donkeys, mules, namely pack animals -, can be found not only on animal figurines from Istakhr but also in a large number of finds from other sites, especially Iran and Iraq.

\subsection{Discussion}

Medieval Islamic clay figurines, both human and animal, are usually interpreted as toys. In particular, the animal specimens would have been toys intended for children during festivities (cf. below). The better known and finest moulded and glazed - sometimes also lustre painted - ceramic figurines produced in Iran during the Seljuk period ${ }^{65}$ have also been compared with the former, even if they were unlikely to have been intended as toys. In recent years Margaret S. Graves dedicated very important and in-depth studies to these small figures, especially the glazed specimens which also include the smaller human and animal glazed figurines placed in those ceramic representations of buildings in miniature commonly referred to as "house models", coeval to the above mentioned Seljuk luxurious figurines. 66

The alternative hypothesis suggested here is that the clay animal figurines from Istakhr and some others from other archaeological sites could be figurines that were intended not as common toys for children made and sold during festivities, but as special animal-shaped artefacts for children to "play with", made and sold during specific festivities for exclusive use during special ceremonies. More specifically, they may be the figurines that children usually placed on the roofs of their houses pending the end of panji-mas and to welcome in the New Year, at the end of a long-lasting ritual of Zoroastrian tradition. ${ }^{67}$ A photo from the

63 Inv. nos. 296/47, 296/48 and 296/49, respectively (Abdullaev - Rtveladze - Shishkina 1991, II, 185, cat. and figs. 722-724). Some clay animal figurines, which J.-C. Gardin (1957, 59-60, 62-63) dated within a very wide period between the $1^{\text {st }}$ and $15^{\text {th }}$ centuries, came from Balkh, in present-day Afghanistan. Among them a horse (Gardin 1957, pl. XI.5), with a muzzle and saddle similar to those of an exemplar from Tell Abū Șkhayr (Shammri 1986, fig. 33d), and a camel (Gardin 1957, pl. XI.4) have some features - such as cylindrical and out-spread legs - quite similar to those of late Sasanian and Islamic specimens.

64 These figurines should be considered products of local craftsmanship, sometimes also with different features even if they come from a single site, and this does not only depend on their dating. See the comparisons previously made by S. Mancini, $\S 1.2$.

65 On these "sculptures" see Grube 1966; Bloom 1975; Treptow 2007, 29-30; Gibson 2008-2009; 2010; 2012; Graves 2008; 2010; 2018.

66 Graves 2008; 2010; 2018.

67 Cf. Boyce 1977, 49, 51 (see also Fontana 2019). 
mid-twentieth century, taken by the famous Zoroastrianism specialist Mary Boyce, ${ }^{68}$ illustrates this occurrence very well (fig. 6). ${ }^{69}$ Boyce was also prodigal with information and in particular she described how the ten-year-old Gushtasp, the youngest member of the Belivani family that hosted her,

«had began to carry the whitened clay [animal] figures ${ }^{[70]}$ up on to the roof while it was still light. [...] Gushtasp was able to carry out [...] his task of taking all the figures up on the roof and arranging them in a quaint row overlooking the courtyard». ${ }^{71}$

Children used to assemble one (or more) row(s) of clay animal figurines along the perimeter of the central open area of the roof corresponding to the courtyard below, as displayed in some Seljuk ceramic house models (figs. 7-10). ${ }^{72}$

The Zoroastrian origin of this ceremony - arguably dating back to earlier times - is likely the reason why a precise prohibition was established ${ }^{73}$ and al-Ghazāli ${ }^{74}$ seems to refer to it twice. M.S. Graves translated a passage from his Arabic work titled Ihyà' 'ulūm al-dīn (The Revival of the Religious Sciences):

«Other objectionable practices include selling musical instruments and models of animals [أشكال الحيو انات الهصورة, ashkāl al-ḥayawānāt al-muṣawwara ${ }^{75}$ ] made for children during the religious festivals [العيد, $\left.a l-{ }^{i} d^{76}\right]$. These latter must be broken and, like musical instruments, their sale must be prevented». ${ }^{77}$

al-Ghazālī returned to this subject later in his Kìmiyā-yi sa'ādat (The Alchemy of Happiness), in Persian, when discussing the science of earning a livelihood according to the law, and presenting the correct characteristics of goods that are subject to bay ' (sale and purchase): ${ }^{.7}$

68 She spent twelve months in Sharīfabād (a village in the Yazdī plain) in 1963-1964 as a guest of the Belivani family and in 1977 published a volume recounting her experiences during this year living in that Zoroastrian community.

69 Boyce's caption reads: «A group of Panji figurines on the Belivani roof, with wind-towers in the background» (Boyce 1977, pl. IVa).

70 As for the whitewashing of the figurines cf. fn. 109, below.

71 Boyce 1977, 224. «[The day after] his [ = of Gushtasp] sisters meantime had gone up to the roof again to fetch the clay figures (which had gazed down on us, white against the blue sky, while we breakfasted below)» (Boyce 1977, 226). Cf., here, fig. 6.

72 See Fontana 2019. Cf. also fn. 89, below.

73 Cf. fn. 87, below.

74 He was born in Ṭūs, eastern Iran, in 1058, and died in 1111.

al-Ghazali, Ihya', II, 333.

al-Ghazali, Ihya', II, 333.

77 Graves 2008, 246; emphasis added

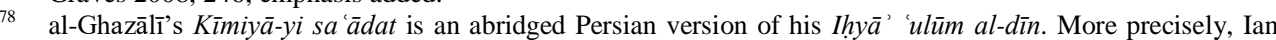
Richard Netton, reviewing a revised and annotated translation by Elton L. Daniel (1991) of Claud Field's (incomplete) 1910 translation from an Urdu version into English of the original Persian Kìmiyā-yi sa'ädat, reported «Daniel tells as that 'in the introduction to the Persian text, Ghazzāli explicitly states that he wrote the Alchemy as an epitome of the Arabic Revivification and some of his other writings, simplified and written in Persian in order to reach a broader, popular audience'» (Netton 1993, 117). Cf. also Bilal ed. 2001, xxiixxiii. 
«As for the clay figurines (صورتها, șurrathā) for children to play with: for any of these that has the shape of an animal, its sale is invalid, its value is unlawful (حر (ح), haram), and it is mandatory to destroy it; but the shape of trees and plants is lawful $(\mid g, \operatorname{rav} \bar{a}) .[\ldots] \gg .{ }^{79}$

In another passage of this work, he dwells on the "misdeeds of the markets" (munkarāt- $i$ $b \bar{a} z \bar{a} r h \bar{a})$ :

«[...] and they sell animal figurines (صورت حيوانات, șūrat-i hayvānāt) for children during the 'ayd (عد), and they sell wooden swords and shields for Nawrūz, and earthen trumpets for Sada. [...] Among these things, some are unlawful (حرام, harām), some are execrable (حكروم, makrūh). As for the animal figurines, they are unlawful (حرام, harām). As for what they sell for Sada and Nawrūz, such as wooden shields and swords, and earthen trumpets, these are not unlawful (حرام نبست, harām nīst) in themselves, but the display of emblems of the Zoroastrians (حبران, Gabrānn) is unlawful (حرام, harm) [...]». ${ }^{80}$

Furthermore, Graves mentions a passage, already cited by Irwin, ${ }^{81}$ in the sixth chapter of the Ma'ālim al-qurba fi ahkām al-hisba ${ }^{82}$ by al-Shāfi' $1 \overline{1}$ Ibn al-Ukhuwwa (Egyptian, d. 1328-9), entitled «Forbidden Commercial Transactions»:

«It is not permitted [...] to sell figurines (الصور, al-ṣuwar) made from clay in the form of animals, which are sold during the festivities (الاعياد, al-a $y \bar{a} d$ ) for children's play, and it is legally mandatory to destroy them, while the figurines of trees are tolerated ${ }^{[83]}$ as for the clothes and dishes with images of animals on them, their sale is lawful (فيصحّ, fa-yașihhu), as is the case for curtains ${ }^{[84]}{ }_{\gg .}{ }^{85}$

79 The English translation from al-Ghazālī’s Persian text (Kïmiyā, I, 330) is by Mario Casari (I am deeply grateful to him); emphasis added.

80 The English translation of Ghazālī’s Kīmiyā, I, 522 is by Mario Casari (emphasis added). For both alGhazālī's Persian passages, cf. also Bilal's translation (Bilal ed. 2001, 471, 474, 694). As regards the latter passage see also Lambton 1968, 277 - even quoted below -, and cf. also Gibson 2010, I, 53 and fn. 39.

81 Graves 2008, 246; 2010, I, 74; Irwin 1977, 173. Cf. also Gibson 2010, I, 54.

82 This work is «a manual for the guidance of persons invested with the office of the hisba ("Censorship") or charged with the duty of maintaining public law and order and the supervision of market dealers and tradesmen» (Levi's introduction to Ibn al-Ukhuwwa 1938, 1).

83 On the tolerance of figurines in the form of trees, cf. the first Persian passage by al-Ghazālī, above. As for trees connected to Zoroastrian ceremonies, also performed in Islamic times and mentioned by Islamic sources - especially Hamza Ișfahānī $\left(10^{\text {th }}\right.$ century) recounting special festivals focusing on a cypress in the Nishapur area - see G. Terribili, Relocating the Prophet's Image. Narrative Motifs and Local Appropriation of the Zarathustra Legend in Pre-/Early Islamic Iran: Iran and the Caucasus 24 (forthc. 2020), in part. fns. 29-36.

84 For a similar sentence concerning the lawfulness of animals depicted on clothes, dishes and curtains, see what was reported earlier by al-Ghazālī (Ihya', II, 334-335; Kìmiyā, I, 330); cf. also Graves 2018, 61 and note 5 For other literary sources discussing this topic see Talbi $(1954,304)$, who quoted the $q \bar{a} d \bar{\imath}$ of Cordova Ibn Rushd (d. 1233) as reported by Muḥammad b. Aḥmad b. Qāsim b. Sa '̄ìd al- 'Uqbānī Tilimsān̄̄ (d. 1467); and Ghabin (2009, 210, and fn. 117), who mentioned both the Hanbalī jurist Ibn Qudāma al-Maqdisī (d. 1223) and the imām al-Mu'ayyad bi-llāh Yahyā ibn Hamza (d. 1344). In my view the lawfulness of these depictions is to be ascribed not only to the use in the private sphere of the objects that reproduce them - on the use of generally figured textiles during prayer see, instead, Flood $(2018,62)$ - but also to the fact that they do not 
Graves properly concluded her argument by saying that «modelled figures of animals in clay, intended for children, were made and sold in medieval Iran and other parts of the Islamic world, were associated with festivals, and were popular enough to require formal laws forbidding their manufacture» and also noted that «these hisba citations do not mention human figures at all». ${ }^{86}$

In my opinion, the fact that human figures are not mentioned among the "forbidden things", which only include animal figurines, confirms that these prohibitions should be understood not as having an iconoclastic purpose, but rather to discourage those ceremonies related to rituals performed by Zoroastrian communities which only involve animal figurines. ${ }^{87}$ As a matter of fact, al-Ghazālī's texts, both Arabic and Persian, ${ }^{88}$ talk not about "toys" but "animal-shaped figures" with which children usually "play" on the occasion of religious festivities (almost certainly Nawrūz in the Persian text). ${ }^{89}$ Thus, I would argue that

have a shadow (and therefore lack realism), as much as they do not deal with those (unlawful) animal figures intended for objectionable Zoroastrian ceremonies, with which, in fact, they are compared.

85 The English translation from Ibn al-Ukhuwwa's Arabic text (1938, 56, at the end of passage no. 78) is by Mario Casari (I wish to express my sincere gratitude to him once again); emphasis added. Cf. also the English translation by Levi in Ibn al-Ukhuwwa 1938, 19. Klein (2006, fn. 15) generically referred to the prohibition of «children's toys [emphasis added]» in other literature; instead, more precisely Ghabin (2009, 210, and fn. 118) mentioned the hisba treaty by al- 'Uqbānī Tilimsānī, who, reporting Ibn Rushd, related what occurred in the $12^{\text {th }}-13^{\text {th }}$-century Cordoba (cf. previous fn.). A summary of this passage can be found in Talbi (1954, 304, emphasis added): «En outre, il [ = Ibn Rushd] réprouvait les jouets en forme d'animaux [الصور الحيوانات, șuwar al-hayawānāt (figurines of animals), after Chenoufi 1965-1966, 243 (9^) - 1. 15], telles les girafes qu'on avait coutume de fabriquer au Nouvel An (nayrūz) en Espagne. 'Uqbānī note à ce propos que la même coutume existait à Tlemcen au mois de janvier et ajoute que, d'une manière générale, on fabriquait des jouets du même genre à l'occasion de toutes les fêtes, coutume qui, à son avis, ne pouvait dénoter qu'une origine chrétienne». This passage is also reported by Casanovas 2001; cf. also Gibson 2010, I, 53-54.

86 Graves 2008, 246 (cf. also Graves 2010, I, 72-73). It is not clear, moreover, what exactly Abū 'l-Qāsim al'Azafì (governor of Ceuta, d. 1278) referred to in his Kitāb al-durr al-munazzam fì mawlid al-nabì almu 'azzam (a text on Christian festivities in al-Andalus), regarding the «figuras prohibidas que ce hacen en el nayrūz, [...]» (de la Granja 1969, 48). As for dolls, see again Graves (2010, I, 74 and fns. 250-251), who referred to Ibn al-Ukhuwwa and al-Ghazālī's Ihya, both reporting the tale of ' $\bar{A}$ ' isha and her dolls. See also alMāwardī, a jurist who was born in Bassora in 972 and died in 1058, who stated: «As for dolls, playing with them does not constitute religious disobedience, but trains girls in bringing up children and in household managements. They do contain an element of sin in that they portray living beings and have some similarity to idols. There are occasions for permitting their handling, and other occasions for preventing it, depending on the evidence in each case. The Prophet, may God bless and grant him peace, entered [a place] where ' $\bar{A}$ ' isha, may God approve of her, was found playing with dolls, and let her be, not objecting to her conduct. [...]» (alMāwardī 1996, 272).

87 Particularly in the Iranian world these animal figurines were likely purchased for children who did not necessarily belong to solely Zoroastrian communities, as supported by the significant production of many Seljuk ceramic house models which could hardly have represented ceremonies performed exclusively within Zoroastrian communities (cf. above, fn. 72 and figs. 7-10). Nevertheless, the incidence and diffusion of the phenomenon must have been such as to justify on the one hand al-Ghazālī's Persian version of his work which could have reached a «broader, popular audience» (cf. above, fn. 78) in his homeland, and on the other hand the requirement of more all-encompassing «formal laws forbidding their [i.e. of the animal figurines] manufacture» (Graves 2008, 246; cf. above).

88 Besides, Ibn al-Ukhuwwa and al- 'Uqbānī Tilimsān̄̄'s texts (for the latter see fns. 84 and 85, above) would seem to be perfectly in accordance with those of al-Ghazālì.

89 Arranging the clay animal figurines in one or more rows on the roof could certainly have appeared as a game to children. 
these animal figures were intended as an inherent part of the above-mentioned Zoroastrian ceremony performed by children, as Ann K.S. Lambton postulated:

«Ghazālī has a curious passage in the Kìmiyā al-sa āda on forbidden things (munkirāt) in a bazaar, which gives a glimpse of the life of the people. Among the items which should not be sold he mentions effigies of animals for children at the holiday ( ${ }^{\mathrm{l}} \mathrm{d}$ ), swords and wooden shields for the Nau-Rūz (the festival of the vernal equinox), and clay pipes for Sada (the festival of the autumnal equinox). These things were not in themselves forbidden but they were a manifestation of Zoroastrian customs, which were contrary to the sharī'a and for this reason unseemly. Further, excessive decoration of the bazaars, making much confectionery and extravagance on the occasion of the Nau-Rūz were not fitting: Nau-Rūz and Sada should be forgotten ${ }^{[90]} \gg .{ }^{91}$

Mary Boyce witnessed this ceremony in the 1960s. ${ }^{92}$ At least three saddled quadrupeds can be identified among the clay animal figurines portrayed on the roof of the Belivani house (fig. 6): a camel, a giraffe, and a donkey or mule carrying loads.

«[...] and on that day [i.e. when children modelled the clay figurines $\left.{ }^{93}\right]$ in the Belivani household Pouran [Gushtasp's fifteen-year-old sister] stitched tiny panniers of homespun cotton to put on the little clay camel, and also some cotton bags. [...]». ${ }^{94}$

Almost all the animal figurines depicting quadrupeds usually intended for riding or carrying loads - found during excavations carried out in the above-mentioned sites, especially from Iran (including Istakhr) and Iraq - wore saddles but were riderless, thus we can assume they were pack animals. ${ }^{95}$ Furthermore, the presence of birds such as the

90 A hadīth is reported in Abū 'l-Qāsim al- 'Azafì's work mentioned above (see fn. 86, above), preceded by a long series of transmitters: «Quien se educa en tierra de no árabes y celebra su nayrūz y su mahraŷān, será juntado con ellos el día del juicio final» (de la Granja 1969, 51). Previously al-'Azafi also stated: «No puede aceptarse de nadie un regalo en el día de nayrūz, ni en la noche del mahraŷān, ni en la noche que llaman "noche de la vieja". El que acepte regalo en esas tres innovaciones, de cualquier persona que sea, se asocia en ellas con los innovadores en el pecado y oprobio que suponen» (de la Granja 1969, 48; for the «noche de la vieja», see de la Granja 1969, fn. 5 on p. 42)

91 Lambton 1968, 277. Cf. also Whitcomb 1985, 190. Furthermore, musical instruments - the sale of which, in close connection with clay animal figurines, al-Ghazālī denounces as prohibited - are held by figures of musicians attending the banquets portrayed in some house models (cf. Graves 2008, 243; 2010, 39, 66-67; 2018, 96; and Scerrato 2014, 16). In a number of al-Ghazālī's passages, Graves seems not to distinguish the prohibition of the sale of musical instruments - together with animal figurines - on the occasion of festivities, from the prohibition of their use, commonly combined with drinking wine (in this regard see also al-Māwardī 1996, 272; cf., here, fns. 86 and 108), she also cites some of Ibn al-Ukhuwwa's passages on the latter interdiction (Graves 2008, 244-245; 2010, I, 68-70).

92 Real people, instead, took part in the following sequence of the ceremony inside the houses, as some house models testify (fig. 7 and cf. fn. 71, above).

93 See fn. 109, below.

94 Boyce 1977, 215. Should the packages represent gifts?

95 As for the horse clay figurines from Vēh Ardashīr (cf. fn. 25, above), dated to the period of the first Sasanian kings, Antonio Invernizzi stated: «Il est donc possible que nos chevaux sassanides de terrecuite, sellés mais sans aucune trace de chevalier, soient à considérer en général complets, sauf que le chevalier ne fût exécuté 
nightingale is also remarkable on both the roof of the Belivani house and among some archaeological finds. Therefore, in my view the reference to the mentioned Zoroastrian ceremony should be carefully considered.

As for some special quadrupeds such as the lions and hyena found at Tell Abū Șkhayr, or a possible cat or lion from Istakhr, as well as oxen or other horned animals from Istakhr, Rayy, Samarra and Wāsiț, ${ }^{96}$ and dogs from Tell Abū Șkhayr, ${ }^{97}$ it is reasonably necessary to again refer to the very probable representation of this ceremony in the glazed pottery house models. Lions or cats (it is very difficult to distinguish between domestic and wild felines) are placed on the roofs of some house models: two such models were auctioned by Christie's and Sotheby's, while another is preserved in the Metropolitan Museum of Art in New York (figs. 8-10). The exemplar once housed at Sotheby's also features some species of horned quadrupeds and possibly dogs too (fig. 10).

The human figures usually seated around a table (in most cases the latter may be set with the haft $\sin )^{98}$ in the courtyards or inner parts of these house models - sometimes both human (inside) and animal (on the roof) figurines are displayed (fig. 7) ${ }^{99}$ - corroborate the hypothesis that most house models represent the events that took place during this celebration of the end of panji-mas, according to the Zoroastrian ceremony for the New Year. ${ }^{100}$

Moreover, M.S. Graves recently rightly referred to the topic of "sweet" citadels or castles populated with figures made on the occasion of festivals and intended as gifts, which she compared to the house models, ${ }^{101}$ actually perfectly fitting the hypothesis proposed herein. In fact, she mentioned the treaty of Abū '1-Qāsim al-'Azafî ${ }^{102}$ where cakes in the form of citadels populated with figures baked by Andalusians for the Nawrūz are mentioned:

«En estas fiestas se hacen unos a otros preciosos regalos que han elegido de antemano, y "ciudades" $\left[\right.$ mada $\left.{ }^{\prime}{ }^{103}{ }^{103}\right]$ en las que forman e inventan diversas figuras (fn. 2: De estas ciudades, prodigio de la repostería [i.e. patisserie]

avec du matériau différent » (Invernizzi 1979, 242). It is also interesting to note the fragment of a thirdcentury clay animal figurine (a horse?) with an attached clay piece on its back (probably the remains of a saddle) from Ardashīr I's (224-241) palace in Qal'a-yi Dukhtar (Huff 1976, 173, fig. 7c and pl. 46.3).

96 Cf. also Merv and Samarkand, above.

97 Cf. also Merv, above.

98 Literally, "seven $\sin$ " (the letter $\sin$ in the Persian alphabet is "s"), i.e. seven objects whose names begin with "s". In this regard and for the number of objects on the tables displayed in the house models, see Graves 2008, 248,; 2010, I, 78; Scerrato 2014, 14, 18, 25.

99 Majda 1989, p. 184, fig. 3; cf. also Fontana 2019, fn. 17 and fig. 2.

100 This interpretation suits the different features which instead characterise some quite coeval $\left(13^{\text {th }}-14^{\text {th }}\right.$ century) clay figurines from Islamic India. The clay horses found during excavations in the Punjab village of Theh Polār, in fact, do not have saddles: they were most likely intended for other purposes (toys also?), according to local ancient traditions (see Banerji 1966, 150-151 and figs. 1-2). As for the intended use of the house models, different opinions are offered by Grube $(1976,174 ; 2003,461)$ and Scerrato $(2014)$, who assumed the ceramic representations of buildings in miniature were wedding gifts; on the intended uses of the house models suggested by Graves, see in particular her last publication on the matter (Graves 2018, $15 \mathrm{ff}$.).

101 Graves 2018, 15, and fn. 42 .

102 See fn. 86, above.

103 Pérès 1937, 304. The latter pointed out: «On donnait à ces gâteaux la forme de villes (madâ'in) et on les appelait madâ 'in min al- 'ağin: "villes de pâte" » (ibid.) 
andaluza, nos ha dejado una buena descriptión Abū 'Imrān Mūsà, poeta de Triana del siglo XI [...])». . $^{04}$

These sweet citadels populated with figures were perhaps not so different from those presented during the banquet in Cairo to celebrate the end of ramadān 380/December 990, as mentioned by the Egyptian historian al-Maqrīzī (d. 1442) in his famous al-Khitaț:

«châteaux de sucre ainsi que les images (en sucre) et les assiettes où étaient des images en confitures (ou pâtisseries). [...] On avait déjà fait dans dâr al fițrat deux châteaux de pâtisserie [...] de forme élégante, vernis de feuilles d'or et dans chacun y avait des figures en relief qu'on aurait dites fondus dans des moules, pièces par pièce». ${ }^{10}$

A similar banquet was described for the end of ramadān 415/December 1024 by 'Izz alMalik Muhammad al-Musabbih̄ī al-Kātib (Egyptian, d. 1029-30) in his Akhbar Miṣr:

«On Friday at the end of Ramadān in 415/1024, a diorama, made of sugar candy and depicting a banquet (simāt $)$ with figurines (timthāl), decorations (tazwīn), and castles (qașr), was paraded through the city streets. Wazir Najīb al-Dawla Abū al-Qāsim 'Alī al-Jarjalā'̄ $\overline{1}$ supervised the display, which boasted 152 figurines and 7 big castles. Officials on horseback and a Sudanese drum corps led the parade, and the people gathered to see it». ${ }^{106}$

Furthermore, in particular these sweet figurines call to mind the animal-shaped hanging sugar candies sold in Cairo as gifts for children, as al-Maqrīzī recounted:

«In the month of Rajab, a beautiful sight appeared in this market: hanging sugar candies ('ilāqa) shaped like horses (khayl), lions ( $s a b$ '), cats (qutta), and more, were hung from threads in front of the shops. They all sold out, as gifts for children, every size of candy, [...] Other markets in Cairo and al-Fusțāt, and even in the suburbs (al-aryāf), were full of similar sugar candies. These same candies were also produced in the month of Sha bān, a custom that continued until quite recently. [...] When sweets production began each Ramadān, the markets of al-Fustât, Cairo, and the suburbs were full of these kinds of sweets». ${ }^{107}$

104 de la Granja 1969, 34. In the introduction to his translation of al- 'Azafi's treaty, de la Granja (1969, 2) stated that «del nayrüz en al-Andalus tenemos sólo unos pocos datos inconexos: la noche que le precedía era considerada por los andaluces como la más propicia para la consumación del matrimonio; en ese día se cocían bolos [ i.e. cakes] en forma de ciudades, se cruzan regalos y [...]». Pérèz $(1937,303)$ specified that « la fête du Nairûz, fête d'origine persane, ne tombe pas le $1^{\text {er }}$ mars comme en Orient, mais les premiers jours de janvier et tend à se confondre, en Espagne musulmane, avec le premier jour de l'année ou mieux, avec le jour de l'Epiphanie », namely the day dedicated to gifts, especially for children.

105 Makrizi 1920, 109-110 [Arabic text in al-Maqrīzī 1854, I, 387]; cf. Ashtor 1968, 1027.

106 Translation by Sato 2015, 58 [Arabic text in al-Musabbiḥ̄ 1978-1984, I (1978), 65].

107 Translation by Sato 2015, 167 [Arabic text in al-Maqrīzī 1854, II, 99-100]; cf. also Sato 2015, 59, 123, 139, 178. On the subject of sweet figures, Mary Boyce can be mentioned again in referring to what went on in the 1960s in the Yazdī plain: «on the last day of Panji mas the dishes baked for consecration included little men made of a sweet dough and animals, stars and the like» (Boyce 2005, 24). For other Muslim sources on both 


\subsection{Final remarks}

Except for cases in which clay animal figurines are dated to the late Sasanian or early Islamic period (up to the $9^{\text {th }}-10^{\text {th }}$ century), the $11^{\text {th }}-13^{\text {th }}$ centuries are chronological references for the very large quantities of more homogeneous finds. The stratigraphy of the 2012 excavation campaign in Istakhr related to the findings of the figurines would suggest a period up to the $12^{\text {th }}$ century (including at least the beginning of the $13^{\text {th }}$ century) and this date fits well with the period in which al-Ghazāli was writing and reporting on the prohibition of these figurines.

It is interesting to note that al-Māwardī of Bassora - who died when al-Ghazālī was born - did not mention a ban on the sale of figurines or musical instruments at public feasts; yet he provided precise rules for the market supervisor with regard to the «use in public of the forbidden musical instruments». ${ }^{108}$ Is it possible that the wide diffusion of the above mentioned ceremony among the Muslim community and the consequent extensive sale of clay animal figurines and musical instruments - the latter accompanying the banquet of Nawrüz and the former to be placed on the roofs of houses by children the night before did not begin until the second half of the $11^{\text {th }}$ century, that is, in the same Seljuk era when the production of ceramic house models also began? It is likely that, just after the Mongol conquest - and with their ongoing prohibition, as Ibn al-Ukhuwwa's passage demonstrated the industrial production of these clay animal figurines slowed down, and they may have been produced not only in lesser quantities and in Zoroastrian-majority areas, but also in small local and seasonal workshops or - as attested for the most recent periods - at home. ${ }^{109}$

Maria Vittoria Fontana

sweet and vegetal essence figures, cf. Graves 2010, I, 80-81, and fns. 274-275; cf. also Gibson 2010, I, 53 and fn. 38. For human and animal figurines «made of gold, silver, and amber, all ornamented with pearls, sapphires, and crysolite» which filled golden trays and were brought on the west bank of the canal in Cairo during the procession ceremony to cut the canal in 517/1123, see Sanders (1994, 105-106 and fn. 47), who cites al-Maqrīzī 1854, I, 473.

108 al-Māwardī 1996, 272; cf., here, fns. 87 and 91. The French translation of al-Māwardī’s text is actually slightly different: «L'usage public d'instruments de jeu ou de musique prohibés » (Mawerdi 1915, 536).

109 In this case, they were most likely not baked. Boyce reported her experience: «[...] it was usually on the first day of Panji-kasog [i.e. the Lesser Pentad], Ruz Aštad of Isfand (Spendarmad) Mah, that boys fetched clay to model figurines for the gahambar-e Panjivak. The figurines were actually shaped on the following day, Ruz Asman, when the worked clay had hardened sufficiently; [...] On the first day [of panji-mas, i.e. the Greater Pentad] Tahmina Khanom [Rustam Belivani's wife] whitewashed the little clay figures, and she and her daughters spread out a white cloth on the clean new floor of the ganza-pak, and arranged all the proper objects beside it: [...] and the charming group of little white figures, the camel with its head to one side, as if craning to see itself in the mirror. The nightingale had a fragrant gourd, striped red and orange, in the hollow of its back, and grapes between its cane legs» (Boyce 1977, 215, 217; see also 220 and 223); «so during Panjī kasōg fine clay was kneaded and shaped into figurines of familiar objects such as camel, donkey and nightingale, with easier, but highly symbolic sugar-cones; and during Panji mas these were whitewashed and placed in the ganza-pāk, the 'pure room' prepared for the visiting souls» (Boyce 2005, 24). More information about the two Pentads are to be found in Boyce (1977, 213 and ff.); for the Iranian festivals of Zoroastrian origin, see also Boyce 1999. Cf. Gibson (2010, I, 55), who mentioned Boyce stating: «Mary Boyce [...] found that yet another of the annual festivals, the sixth gāhambār which celebrated creation and took place just before Nawrüz, was also celebrated with the production of figurines». 


\section{REFERENCES}

Abdullaev, K.A. - Rtveladze, E.V. - SishKinA, G.V. (eds.)

1991 Culture and Art of Ancient Uzbekistan. Exhibition Catalogue, 2 vols., Moscow 1991. ADAMS, R.McC.

1970 Tell Abu Sarīfa: A Sassanian - Islamic Ceramic Sequence from South Central Iraq: Ars ASHTOR, E. Orientalis 8 (1970), pp. 87-119.

1968 Essai sur l'alimentation des diverses classes sociales dans l'Orient médiéval: Annales.

BANERJi, A. Economies, sociétés, civilisations 23.5 (1968), pp. 1017-1053.

1966 Clay Figurines in the Muslim Period: Journal of the Asiatic Society (Calcutta) 8.3 (1966), pp. 149-151.

BILAL, M.A. (ed.)

2001 Kìmiyā-i-Sa 'ādat (Alchemy of Eternal Bliss) by Imam Ghazzali, Lahore 2001.

BLOOM, J.M.

1975 "Raqqa” Ceramics of the Freer Gallery of Art, Washington, D.C., MA Thesis, University of Michigan, Ann Arbor 1975 (unpublished).

BOYCE, M

1977 A Persian Stronghold of Zoroastrianism (Persian Studies Series 12), Oxford 1977.

1999 Festivals i. Zoroastrian: Encyclopadia Iranica IX.5 (1999), pp. 543-546.

2005 Further on the Calendar of Zoroastrian Feasts: Iran 43 (2005), pp. 1-38.

BRUNNER, CH.J.

1980 Sasanian Seals in the Moore Collection: Motive and Meaning in Some Popular Subjects: Metropolitan Museum Journal 14 (1980), pp. 33-50.

Casanovas, $\mathrm{M}^{\mathrm{a}}$.A

2001 Figura zoomorfa - شكل حيو - Zoomorphic Figure: I. CORTÉs (ed.), El esplendor de los Omeyas cordobeses: La civilización musulmana de Europa Occidental, Exposición en Madīnat al-Zahrā', 3 de mayo a 30 de septiembre de 2001. Catálogo de piezas, Granada 2001, p. 181.

Cellerino, A. - Messina, V.

2013 Terracotta Animal Figurines from Veh Ardashir (Coche) in the Collection of the Museo Civico d'Arte Antica e Palazzo Madama (Torino): A. PeruzzetTo - F. Dorna MetzGer L. DiRVEN (eds.), Animals, Gods and Men from East to West: Papers on Archaeology and History in Honour of Roberta Venco Ricciardi (BAR International Series 2516), Oxford 2013, pp. 123-134.

CHenoufi, A.

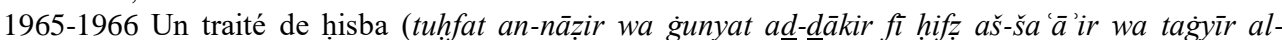
manākir) de Muhammad al- 'Uqbānī at-Tilimsānī (jüriste mort à Tlemcen en 871/1467): Bulletin d'études orientales 19 (1965-1966), pp. 133, 135-152, 154-342, 344.

CHRISTIE'S

2008 Indian and Islamic Works of Art and Textiles (sale 5331, South Kensington, 11 April 2008), London 2008.

Di CESARE, M. - EBANISTA, L.

2018 The Site of the Mosque at Istakhr: M.V. FonTANA (ed.), Istakhr (Iran), 2011-2016: Historical and Archaeological Essays (Quaderni di Vicino Oriente XIII), Roma 2018, pp. 251-301. 
FEHÉRVÁRI, G.

1996 Islamic Pottery: G. FehÉRvÁRI - W.G. LAMBERT - R.H. PINDER-WiLSON - M. WenZel FLOOD, F.B. (eds.), Art of the Eastern World (Hadji Baba Ancient Art), London 1996, pp. 116-193.

2018 Bodies, Books, and Buildings: Economies of Ornament in Juridical Islam: D. GANZ - B. Schellewed (eds.), Clothing Sacred Scriptures: Book Art and Religion in Christian, Islamic, and Jewish Cultures, Berlin 2018, pp. 49-67.

FONTANA, M.V.

2018 (ed.), Istakhr (Iran), 2011-2016: Historical and Archaeological Essays (Quaderni di Vicino Oriente XIII), Roma 2018.

2019 A New Understanding of the Seljuq Ceramic Models of Houses. A Review Article: FusARO, A. Annali dell'Orientale di Napoli 79 (2019), pp. 306-315.

2016 1. Pottery Finds: A General Overview: Fontana, M.V. - Asadi, A.A. - Rugiadi, M. Felici, A.C. - Fusaro, A. - Mancini, S., 'Estakhr Project - Third Preliminary Report of the Joint Mission of the Iranian Center for Archaeological Research, The ParsaPasargadae Research Foundation and the Sapienza University of Rome, Italy': Vicino Oriente XX (2016), pp. 86-90.

Gaibov, V. - Koshelenko, G. - Novikov, S.

1990 Chilburj: Bulletin of the Asia Institute N.S. 4 (1990), pp. 21-36.

GARDIN, J.-C.

1957 Céramiques de Bactres (Mémoires de la Délégation Archéologique Française en Afghanistan 15), Paris 1957.

GHABIN, A.

2009 Hisba, Arts and Craft in Islam (Arabisch-Islamische Welt in Tradition und Moderne 7) Wiesbaden 2009.

AL-GHAZĀLī, Ihya'

1957 Ihya' 'ulūm al-dīn, ed. BADAWĪ ȚABĀNA, 4 vols., Cairo 1957.

AL-GHAZĀLì, Kìmiyā

1380/2002 Kìmiyā-yi sa àdāt, ed. HuSAYN KHIDĪVJAM, 2 vols., Tehrān 1380/2002 (9 $9^{\text {th }}$ edition).

GIBSON, M.

2008-2009 The Enigmatic Figure: Ceramic Sculpture from Iran and Syria c. 1150-1250: Transactions of the Oriental Ceramic Society 73 (2008-2009), pp. 39-50.

2010 Takūk and Timthāl: A Study of Glazed Ceramic Sculpture from Iran and Syria circa 1150-1250, PhD Thesis, 2 vols., School of Oriental and African Studies, University of London, London 2010 (unpublished).

2012 Ceramic Sculpture from the Medieval Islamic World: Hadeet ad-Dar, The Journal of the Dar al-Athar al-Islamiyyah 35 (2012), pp. 24-28.

GRANJA, F. DE LA

1969 Fiestas cristianas en al-Andalus (materiales para su estudio), I: «Al-Durr al-munazzam» de al- 'Azafi: Al-Andalus 34.1 (1969), pp. 1-53 (repr. F. de la Granja Santamaría, Estudios de Historia de Al-Andalus, Madrid 1999, pp. 187-273).

GRAVES, M.S.

2008 Ceramic House Models from Medieval Persia: Domestic Architecture and Concealed Activities: Iran 46 (2008), pp. 227-251.

2010 Worlds Writ Small. Four Studies on Miniature Architectural Forms in the Medieval Middle East, $\mathrm{PhD}$ Thesis, 3 vols., University of Edinburgh, Edinburgh 2010 (unpublished).

2018 Arts of Allusion: Object, Ornament, and Architecture in Medieval Islam, Oxford 2018. 
GRUBE, E.J.

1966 Islamic Sculpture: Ceramic Figurines: Oriental Art 12 (1966), pp. 165-175.

1976 Islamic Pottery of the Eighth to the Fifteenth Century in the Keir Collection, London 1976.

2003 An Unidentified Ceremony: M.V. FontanA - B. Genito (eds.), Studi in onore di Umberto Scerrato per il suo settantacinquesimo compleanno (Series Minor 65), 2 vols., Napoli 2003, II, pp. 457-463.

HERRMANN, G. - KURBANSAKHATOV, K. ET AL.

1994 The International Merv Project - Preliminary Report on the Second Season (1993): Iran 32 (1994), pp. 53-75.

Herrmann, G. - KuRbansakHatov, K. - Simpson, St J.

1997 The International Merv Project - Preliminary Report on the Fifth Season (1996): Iran 35 (1997), pp. 1-33.

2000 The International Merv Project - Preliminary Report on the Eighth Season (1999): Iran 38 (2000), pp. 1-31.

HUFF, D

1976 Ausgrabungen auf Qal'a-ye Dukhtar: Archaeologische Mitteilungen aus Iran N.F. 9 (1976), pp. 157-173.

IBN AL-UKHUWWA

1938 The ma'ālim al-qurba fì ahkām al-hisba of Diyā al-Dīn Muhammad ibn Muhammad alQurashī al-Shāfi ī̄, Known as Ibn Ukhuwwa, Edited, with Abstract of Contents, Glossary, Indices by Reuben Levi (E.J.W. Memorial Series N.S. 12), London 1938.

INVERNIZZI, A.

1979 Figurines de terrecuite de Coche (Ctesiphon): Akten des VII. Internationalen Kongress für Iranische Kunst und Archäologie, München 7.-10. September 1976 (Archäologische Mitteilungen aus Iran 6), Berlin 1979, pp. 241-246.

1985 Catalogue entries nos. 159-162: La terra tra i due fiumi: Venti anni di archeologia italiana in Medio Oriente. La Mesopotamia dei tesori (Firenze 1986), Firenze 1985 [sic], 132-133.

IRWIN, R.

1977 Islamic Art, London 1977.

JoEL, G. - PELI, A.

2005 Suse. Terres cuites islamiques (ed. S. MAKARIOU), Paris 2005.

KERVRAN, M.

1977 Les niveaux islamiques du secteur oriental du tépé de l'Apadana. II. Le matériel céramique: Cahiers de la Délégation Archéologique Française en Iran 7 (1977), pp. 75 161.

1984 Le matériel archéologique: in M. KERVRAN - A. RougelLe, 'Recherches sur les niveaux islamiques de la Ville des Artisans, Suse 1976-1978': Cahiers de la Délégation KIANI, M.Y Archéologique Française en Iran 14 (1984), pp. 50-93, 139-143.

1984 The Islamic City of Gurgan (Archaeologische Mitteilungen aus Iran 11), Berlin 1984.

KLEIN, Y.

2006 Between Public and Private: An Examination of Hisba Literature: Harvard Middle Eastern and Islamic Review 7 (2006), pp. 41-62.

LAMBTON, A.K.S.

1968 The Internal Structure of the Saljuq Empire: J.A. Boyle (ed.), The Cambridge History of Lo MuZio, C. Iran 5. The Saljuq and Mongol Periods, Cambridge 1968, pp. 203-282.

2010 Unpublished Terracotta Figurines from the Bukhara Oasis: P. CALlieri - L. Colliva (eds.), South Asian Archaeology 2007. Proceedings of the 19th Meeting of the European 
Association of South Asian Archaeology in Ravenna, Italy, July 2007, II. Historic Periods (BAR International Series 2133), Oxford 2010, pp. 179-190.

MAJDA, T.

1989 Collection of Islamic Tiles and Ceramics in the National Museum in Warsaw: First International Congress on Turkish Tiles and Ceramics (Kütahya, 6-11. VII. 1986), Istanbul 1989, pp. 181-190.

MAKRIZI

1920 Description historique et topographique de l'Égypte traduit par M. Paul Casanova. Quatrième partie, premier fascicule (Mémoires publiés par les membres de l'Institut français d'archéologie orientale du Caire sous la direction de M. George Foucart 4), Le Caire 1920

AL-MAQRİZİ

1854 Kitāb al-Mawā'iz wal-I tibār bi-Dhikr al-Khițaț wal-Āthār, 2 vols., Bulaq 1270H/1854.

MARTINEZ-SÈVE, L.

2002 Les figurines de Suse : de l'époque néo-élamite à l'époque sassanide, Paris 2002.

2003 Sur les figurines animalières de Suse (Iran): Anthropozoologica 38 (2003), pp. 49-59.

AL-MĀWARDī

1996 The Ordinances of Government. Al-Ahkām al-Sulțāniyya w'al-Wilāyāt al-Dìniyya (The Center for Muslim Contribution to Civilization), transl. by WAFAA H. WAHBA, Reading 1996.

MAWERDI

1915 Les statuts gouvernementaux ou règles de droit public et administratif, traduits et annotés AL-MusABBițī par E. Fagnan, Alger 1915.

1978-1984 al-Juz' al-arba 'ūn min Akhbār Miṣr. Tome quarantième de la Chronique d'Égypte de Musabbiḥ̄ (Textes arabes et études islamiques 13), eds. AYMAN FU'ĀD SAYYID - T. BIANQUIS - HUUSAYN NAȘȘĀR, 2 vols., al-Qāhira 1978-1984.

NETTON, I.R.

1993 Review of "The Alchemy of Happiness. By Abū Hamid Muhammad al-Ghazzālī. Translated by Claud Field Revised and Annotated by Elton L. Daniel, NY 1991": The PARAYRE, D. Journal of the Royal Asiatic Society $3^{\text {rd }}$ S. 3.1 (1993), pp. 117-118.

2003 Les figurines animales dans le Proche-Orient ancien aux époques historiques: Anthropozoologica 38 (2003), pp. 17-34.

PÉRÈs, H.

1937 La poésie andalouse en arabe classique au XI ${ }^{e}$ siècle : ses aspects généraux et sa valeur documentaire (Publications de l'Institut d'Études Orientales, Faculté des Lettres d'Alger 5), Paris 1937.

Pugachenkova, G.A.

1962 Koroplastic of Ancient Merv: Trudy IUzhno-Turkmenistanskoi arkheologicheskoi kmpleksnoi ekspeditsii (Ashkhabad) 2 (1962), pp. 117-173 [non vidi].

PUSCHNIGG, G.

2006 Ceramics of the Merv Oasis: Recycling the City, Walnut Creek, Ca. 2006.

ROSEN-AyALON, M.

1974 Ville royale de Suse, IV. La poterie islamique (Mémoires de la Délégation Archéologique en Iran 50, Mission de Susiane), Paris 1974. 
Rugiadi, M. - Colliva, L.

2018 On the Ground. The Archaeological Site of Istakhr: M.V. FonTANA (ed.), Istakhr (Iran), 2011-2016: Historical and Archaeological Essays (Quaderni di Vicino Oriente XIII),

SAFAR, F.

$1945 \quad$ Wâsit: The Sixth Season's Excavations, Le Caire 1945.

SAMARCANDE

1992 Terres secrètes de Samarcande : Céramiques du VIII au XIII siècle (Institut du Monde Arabe, Paris - Musée de Normandie, Caen - Musée des Augustins, Toulouse 1992-1993), Paris 1992.

SANDERS, P.

1994 Ritual, Politics, and the City in Fatimid Cairo (SUNY Series in Medieval Middle East History, ed. by J. Bacharach), Albany 1994.

SARRE, F.

1925 Die Ausgrabungen von Samarra, II. Die Keramik von Samarra (Forschungen zur Islamischen Kunst 2), Berlin 1925.

SATO, T.

2015 Sugar in the Social Life of Medieval Islam (Islamic Area Studies 1), Leiden - Boston 2015.

SCANLON, G.T.

1968 Ancillary Dating Materials from Fustat: Ars Orientalis 7 (1968), pp. 1-17.

SCERRATO, U.

2014 Hausmodelle: M.V. Fontana (ed.), Umberto Scerrato. Saggi inediti e opera minora (Quaderni di Vicino Oriente VII), 3 vols., Roma 2014, I, pp. 14-46.

SCHMIDT, E.F.

1939 The Treasury of Persepolis and Other Discoveries in the Homeland of the Achaemenians (Oriental Institute Communications 21), Chicago 1939.

$1940 \quad$ Flights over Ancient Cities of Iran, Chicago 1940.

SHAMMRI, H.A.

1986 Islamic Metalwork and Other Related Objects from the Excavations at Tall Abu Șkhayr, al-Daura, Baghdad, PhD Thesis, School of Oriental and African Studies - University of SIMPSON, ST J. London, London 1986 (unpublished).

2004 Glass and Small Finds from Sasanian Contexts at the Ancient City-Site of Merv: Central Asia from the Achaemenids to the Timurids: Archaeology, History, Ethnology, Culture. Materials of an International Scientific Conference Dedicated to the Centenary of Aleksander Markovich Belenitsky (St. Petersburg November 2-5, 2004), St. Petersburg 2004, pp. 232-238.

Simpson, St J. - HERRMANN, G.

1995 'Through the Glass Darkly' Reflections on some Ladies from Merv: Iranica Antiqua 30 (1995), pp. 141-158.

SOTHEBY's

2013 Sotheby's Arts of the Islamic World (sale L13223, 9 October 2013), London 2013.

SPYCKET, A.

1992 Terracotta Figurines: P.O. HARPER - J. ARUZ, - F. TAllon (eds.), The Royal City of Susa:

TALBI, M.

1954 Quelques données sur la vie sociale en Occident musulman d'après un traité de hisba du XV siècle: Arabica 1.3 (1954), pp. 294-306. 
TAMPOE, M.

1989 Maritime Trade between China and the West: An Archaeological Study of the Ceramics from Siraf (Persian Gulf), 8th to 15th Centuries A.D. (BAR International Series 555), Oxford 1989.

TREPTOW, T.

2007 (with the collaboration of D. Whiтcomb), Daily Life Ornamented: The Medieval Persian WELLS, R.D. City of Rayy (Oriental Institute Museum Publications 26), Chicago 2007.

2015 Settlement in the Diyala and Southern Mesopotamia: A Reassessment of Robert McCornick Adams' Sasanian and Early Islamic Ceramic 'Type Fossils', M.A. Thesis, Durham University, Durham 2015 (unpublished).

WHITBREAD, I.K.

1986 The Characterisation of Argillaceous Inclusions in Ceramic Thin Sections: Archaeometry 28.1 (1986), pp. 79-88.

Wнітсомв, D.S.

1985 Before the Roses and Nightingales. Excavations at Qasr-i Abu Nasr, Old Shiraz, New York 1985.

WILKINSON, CH.K.

1973 Nishapur: Pottery of the Early Islamic Period, New York [1973]. 

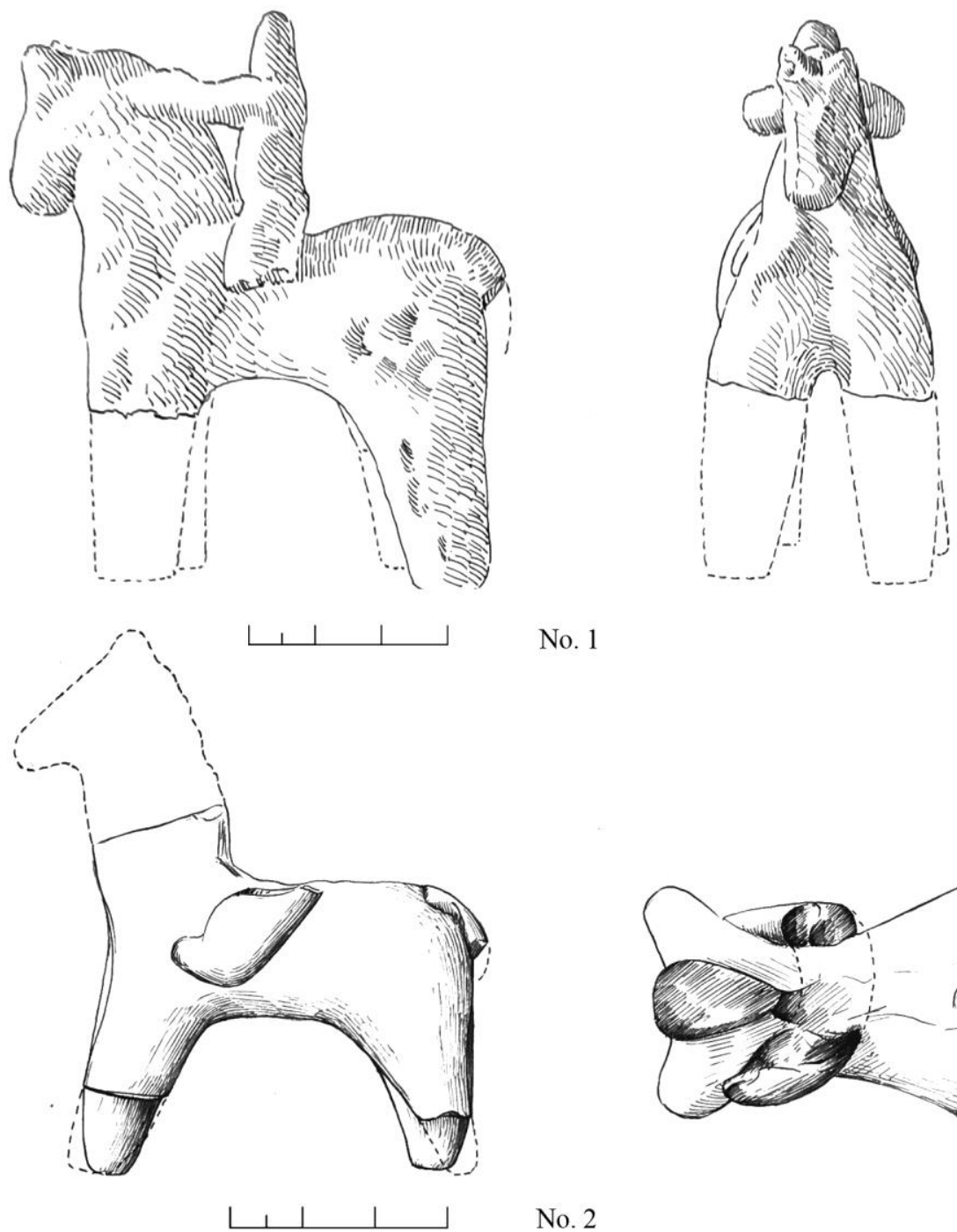

No. 1

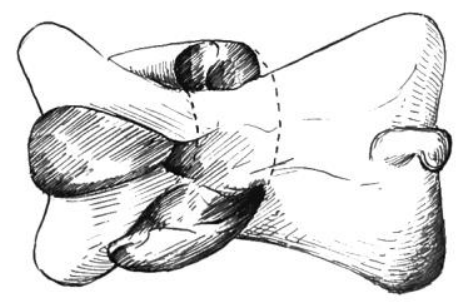

No. 2

Fig. 1 - Clay figurines from the 1930s excavations at Istakhr: two saddleless horses with riders (nos. 1 and 2), $11^{\text {th }}$-early $13^{\text {th }}$ century (C) Oriental Institute Museum, Chicago). 

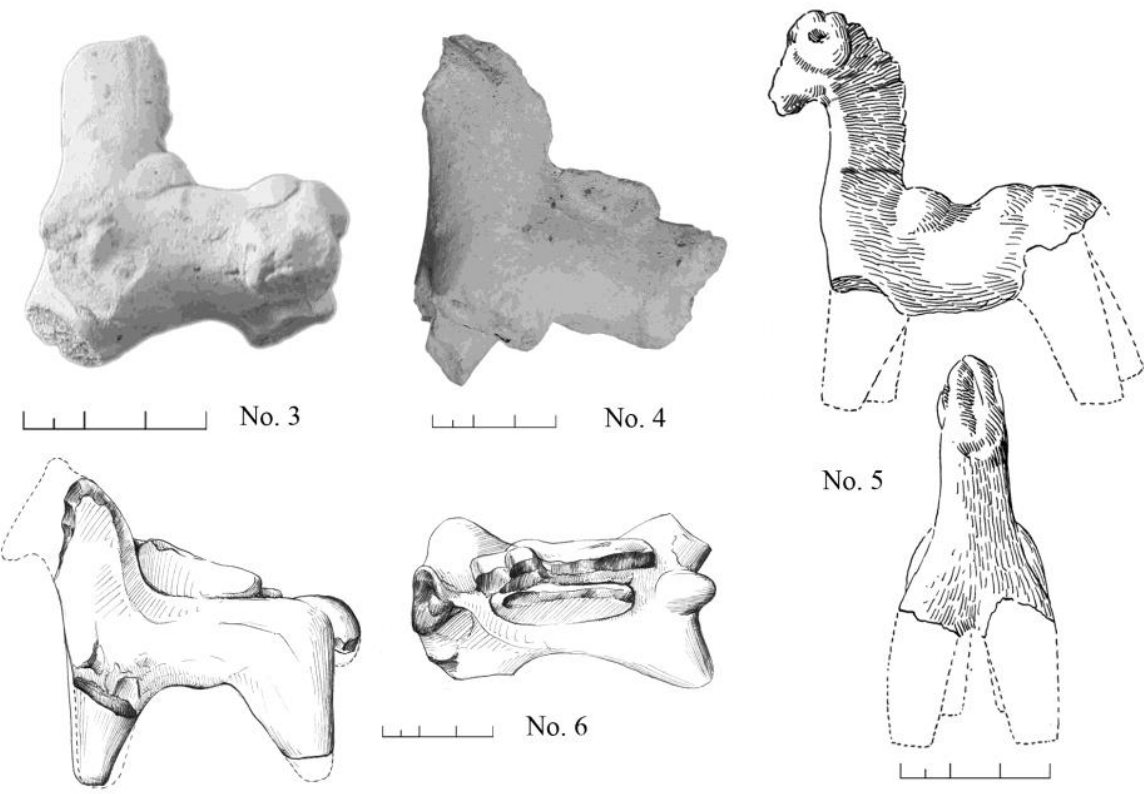

No. 6
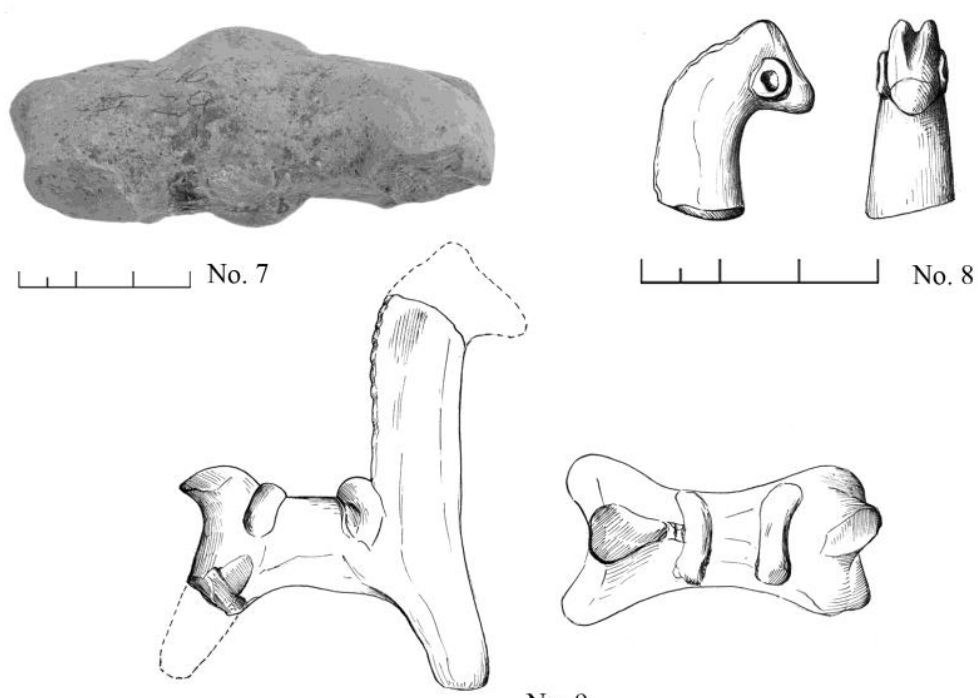

No. 9

Fig. 2 - Clay figurines from excavations at Istakhr: two saddled horses (nos. 3 and 4) unearthed in 2012; three saddled horses (nos. 5, 6 and 7), a horse's head (no. 8) and a saddled horse or, most likely, a giraffe (no. 9) unearthed in the $1930 \mathrm{~s}, 11^{\text {th }}$-early $13^{\text {th }}$ century (nos. 5-9 @ Oriental Institute Museum, Chicago). 


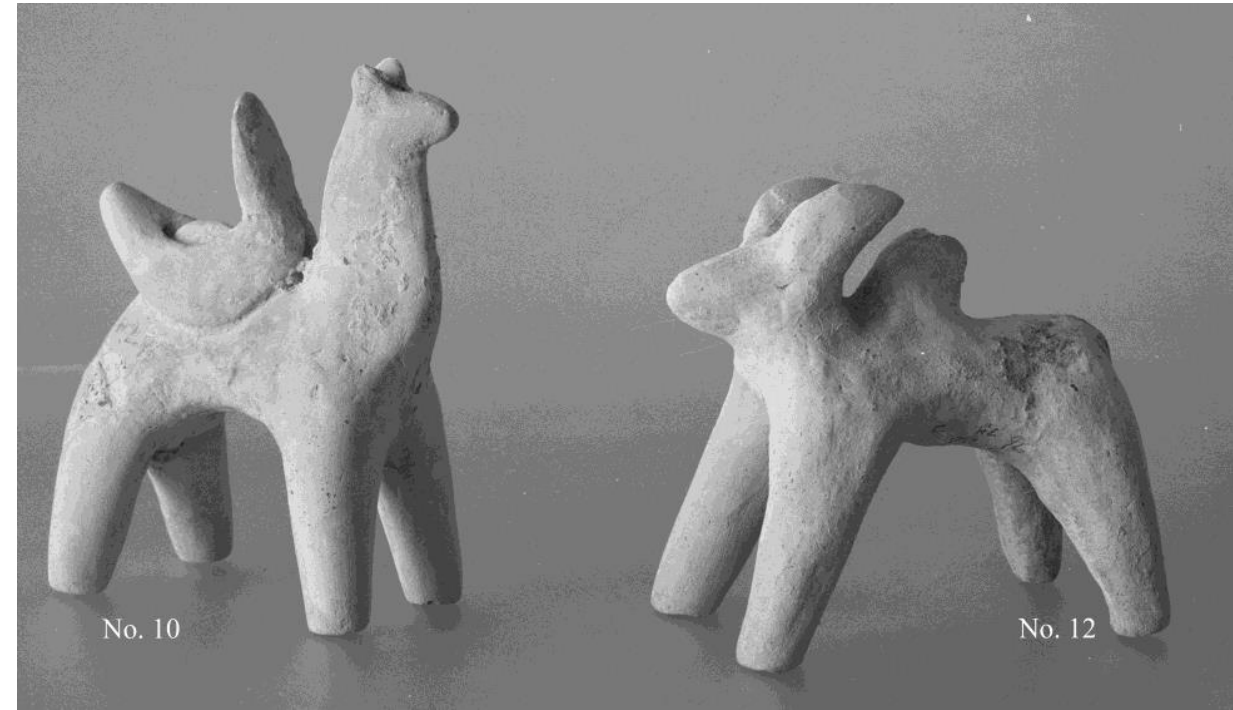

Fig. 3 - Clay figurines from the 1930s excavations at Istakhr: a saddled horse (no. 10) and a horned animal (probably a gibbous ox, no. 12), $11^{\text {th }}$-early $13^{\text {th }}$ century (after Schmidt 1939 , fig. 85).
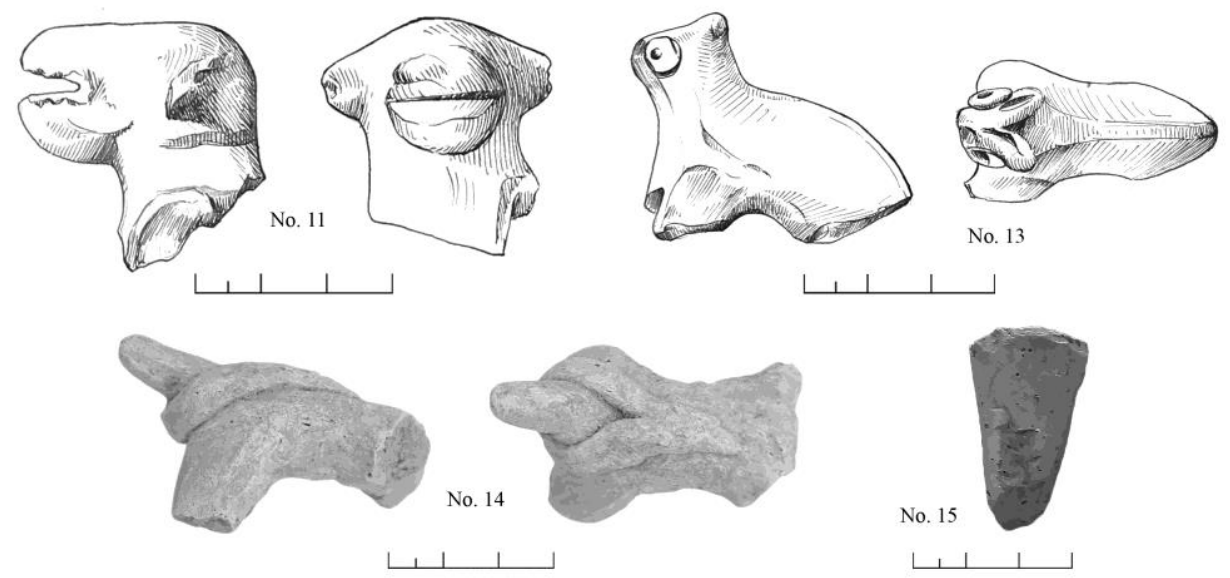

Fig. 4 - Clay figurines from excavations at Istakhr: a camel's head (no. 11), a cat or lion (no. 13), an unidentified quadruped (no. 14) unearthed in the 1930 excavations, and a quadruped's leg (no. 15) unearthed in $2012,11^{\text {th }}$-early $13^{\text {th }}$ century (nos. 11,13 and 14 (C) Oriental Institute Museum, Chicago). 

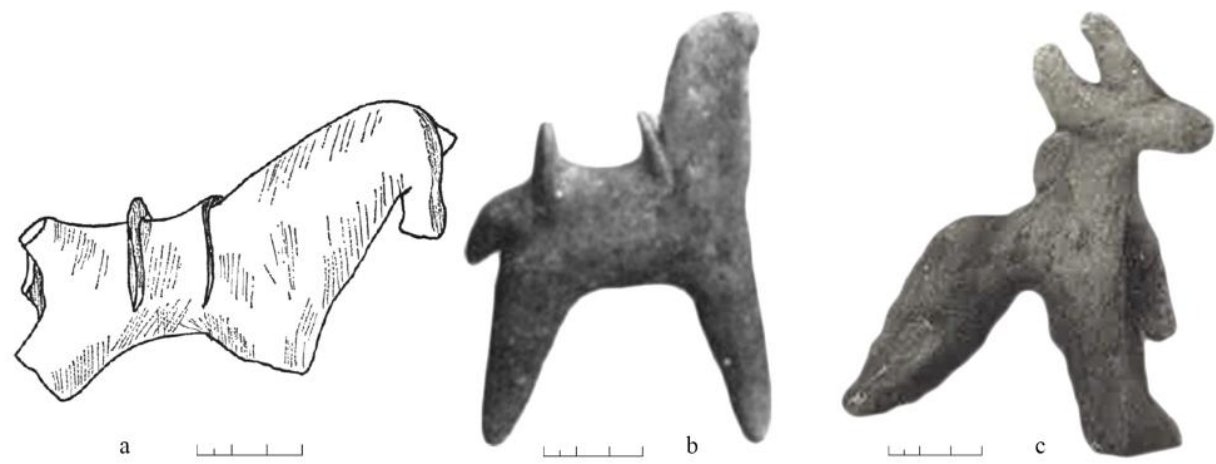

Fig. 5 - Clay figurines of quadrupeds from Susa (Iran; saddled horse, after Rosen-Ayalon 1974, fig. 248), Tell Abū Sarīfa (Iraq; saddled horse, after Adams 1970, pl. 8, fig. 16e) and Wāsit (Iraq; gibbous ox, after Safar 1945, pl. XXII $a$ ), dated to the mid- $7^{\text {th }}-8^{\text {th }}$ century, $9^{\text {th }}$ $10^{\text {th }}$ century, and $13^{\text {th }}$ century, respectively.

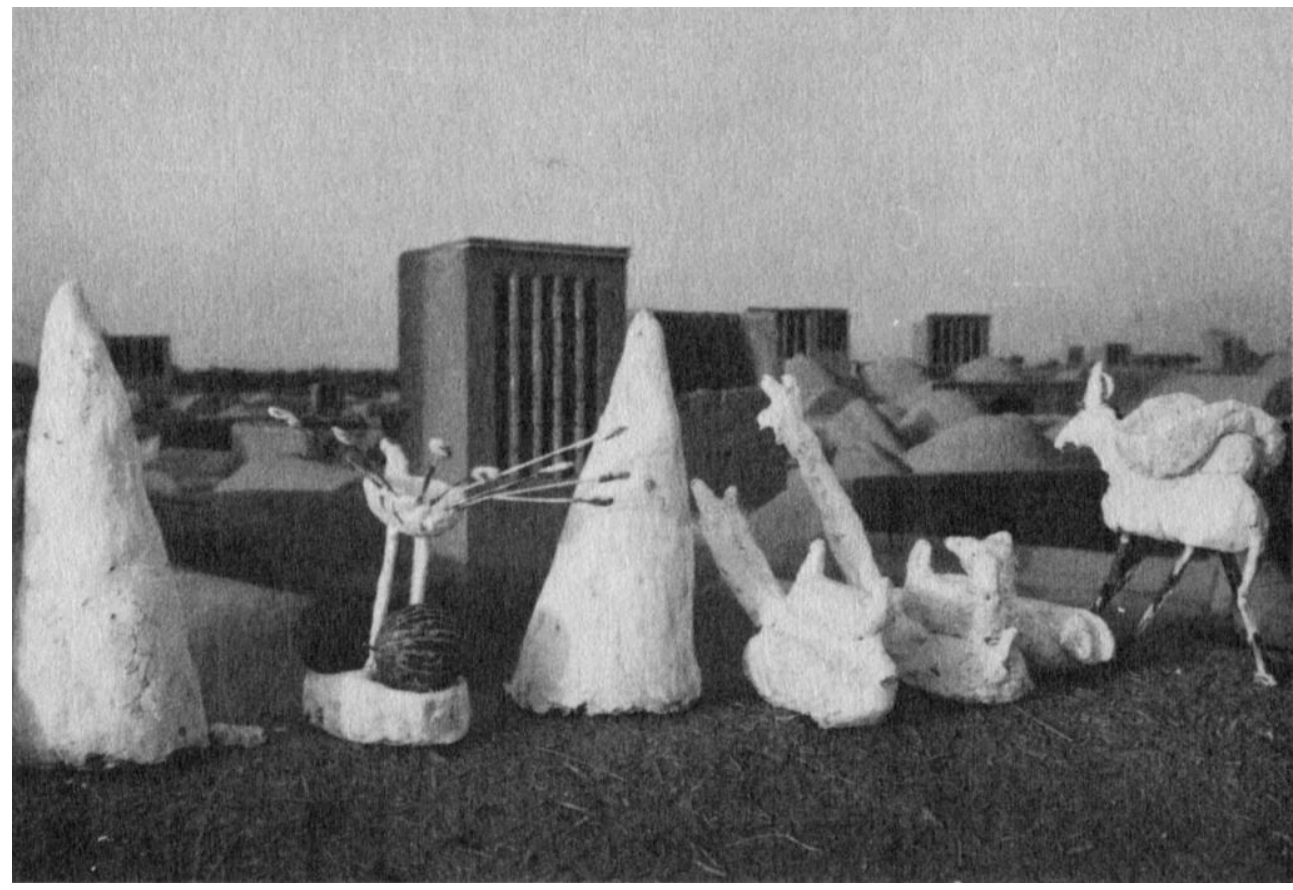

Fig. 6 - A row of clay figurines in the shape of saddled quadrupeds and a nightingale on the roof of a Zoroastrian house in the Yazdī plain, overlooking the courtyard (after Boyce 1977, pl. IVa). 


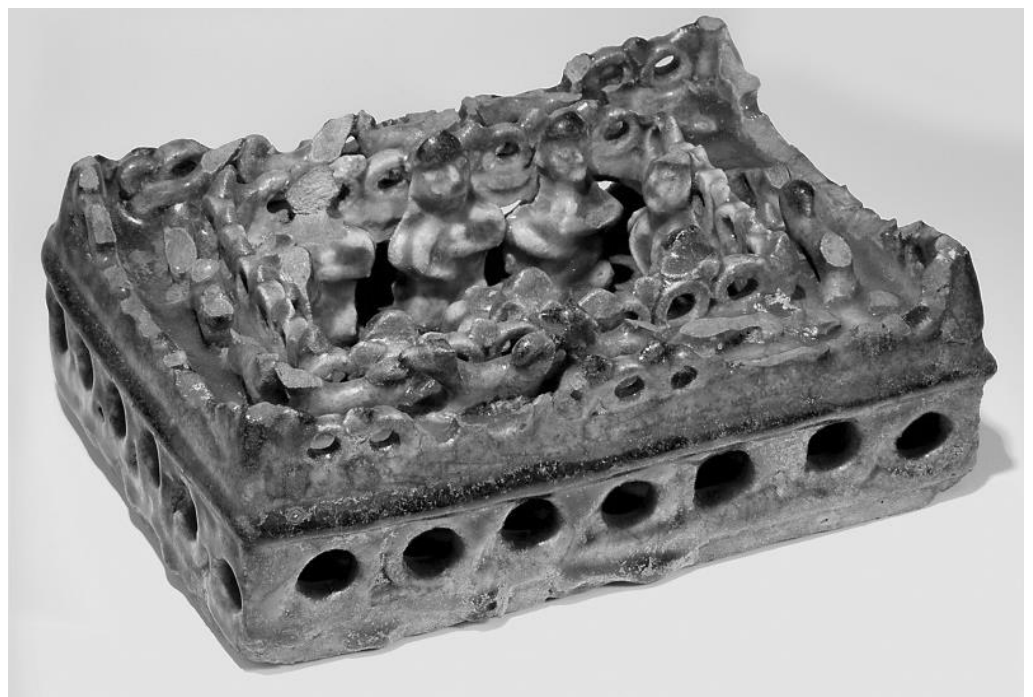

Fig. 7 - House model showing a row of (damaged) quadrupeds on the roof and some people attending a banquet inside, stonepaste glazed in transparent turquoise with blue painting, Iran, $12^{\text {th }}$-early $13^{\text {th }}$ century, Warsaw, National Museum, Inv. SKAZsz 2263 MNW (http://masterpieces.asemus.museum/masterpiece/detail.nhn?objectId=14188).

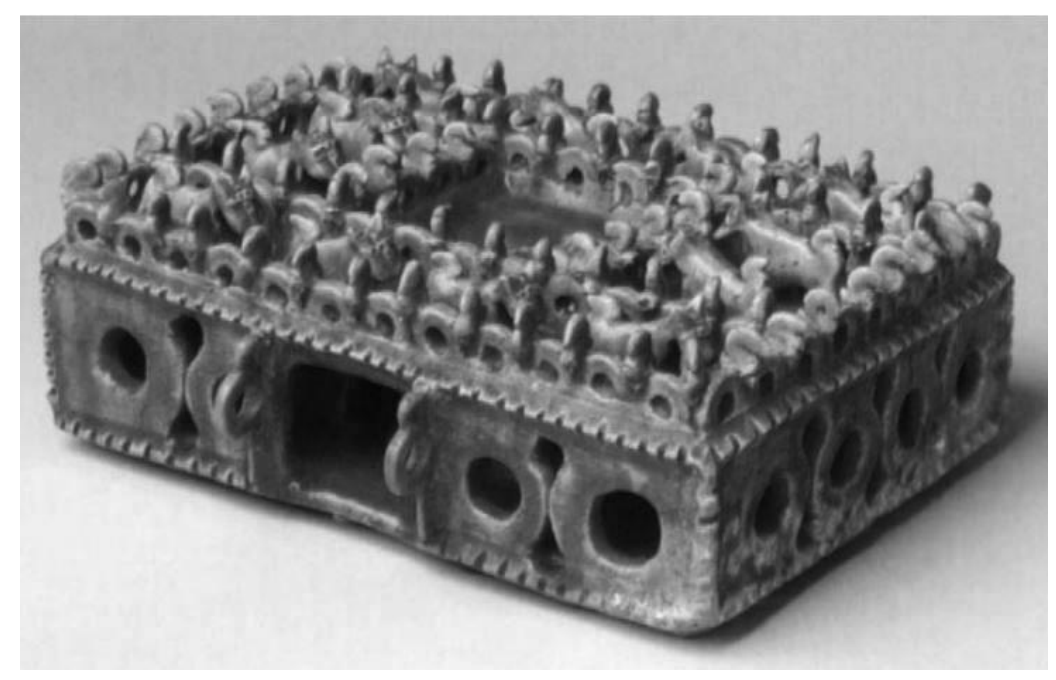

Fig. 8 - House model showing a row of lions or cats on the roof, stonepaste glazed in transparent blue, Iran, $12^{\text {th }}$-early $13^{\text {th }}$ century, New York, The Metropolitan Museum of Art, Goldman Sachs Gift, 2007, Inv. 2007.354 (once Hadji Baba Gallery, London) (after Fehérvári 1996, ill. on p. 151). 


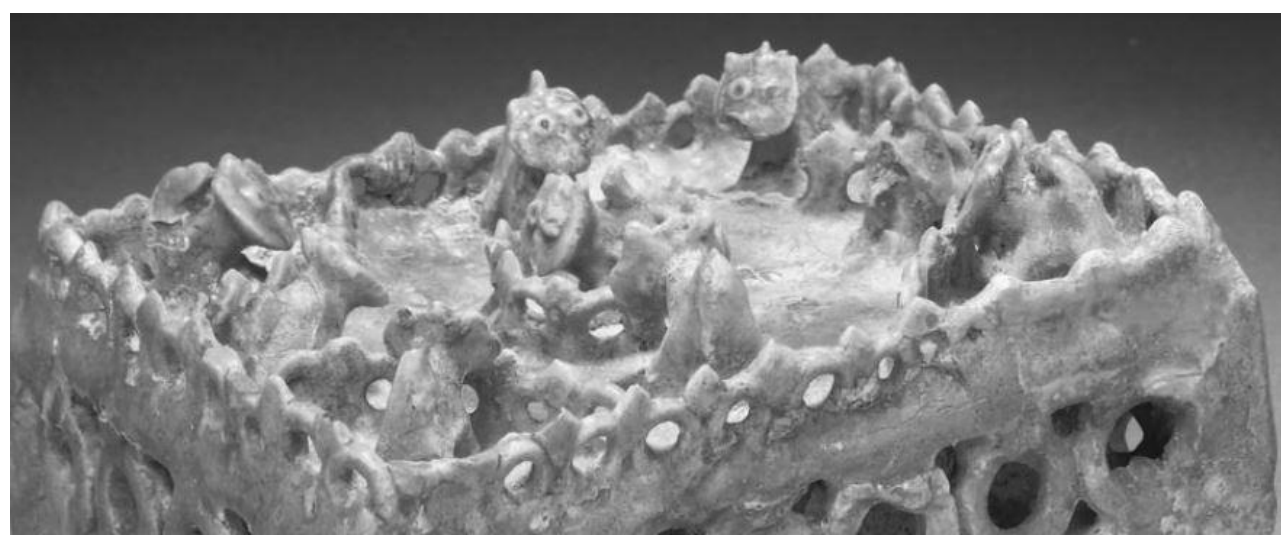

Fig. 9 - House model showing lions or cats on the roof, stonepaste glazed in transparent turquoise, Iran, $12^{\text {th }}$-early $13^{\text {th }}$ century, detail (after Christie's 2008, lot 274).

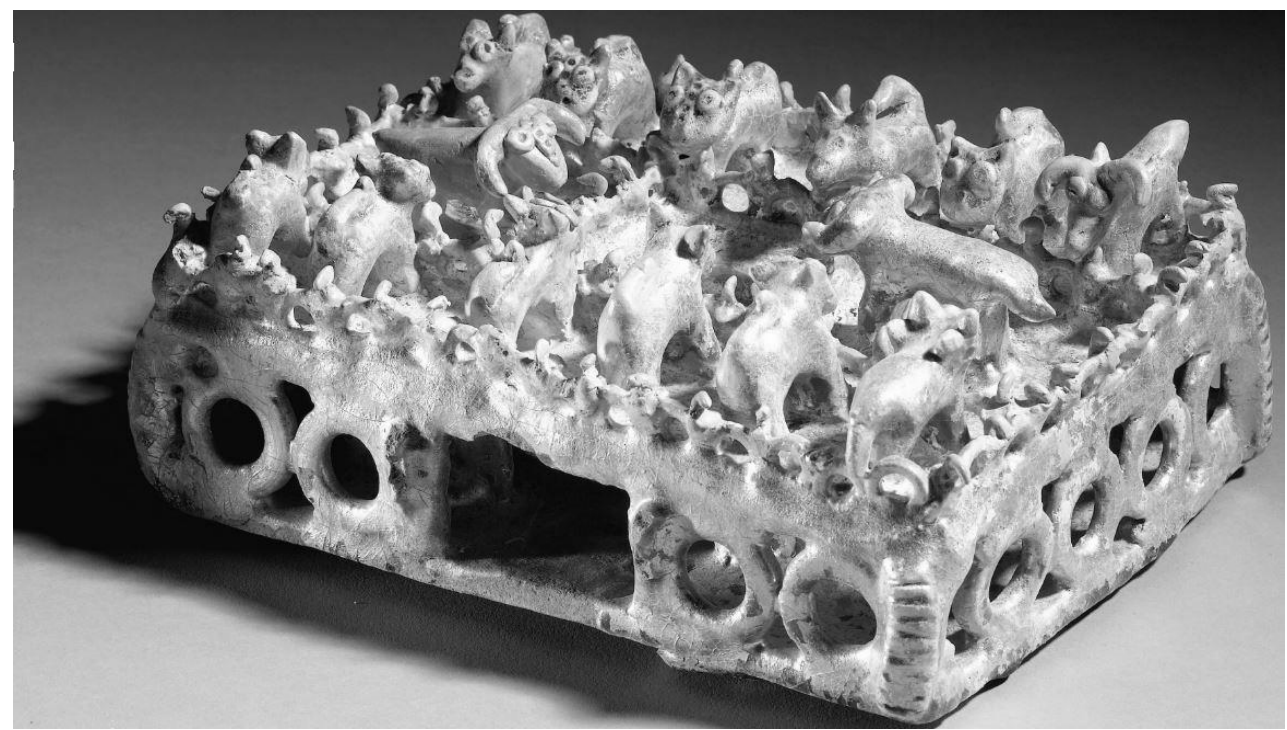

Fig. 10 - House model showing lions or cats, horned animals and perhaps dogs on the roof, stonepaste glazed in transparent turquoise, Iran, $12^{\text {th }}$-early $13^{\text {th }}$ century (after Sotheby's 2013, lot 19). 